\title{
高速道路盛土の地震災害マネジメント における耐震性評価手法の構築
}

\author{
中村 洋丈 1 ・横田 聖哉 2 ・吉村 雅宏3 \\ 1正会員 株式会社高速道路総合技術研究所 道路研究部（干194-8508 東京都町田市忠生1-4-1） \\ E-mail: h.nakamura.ag@ri-nexco.co.jp \\ 2正会員 東日本高速道路株式会社 東北支社秋田管理事務所（ $\bar{T}$ 010-1404 秋田市上北手古野字大繋沢30-2） \\ E-mail: s.yokota.aa@e-nexco.co.jp \\ 3正会員 株式会社高速道路総合技術研究所 道路研究部（干194-8508 東京都町田市忠生1-4-1） \\ E-mail: m.yoshimura.aa@ri-nexco.co.jp
}

\begin{abstract}
震災害時には高速道路は緊急交通路の機能を有し， “線”として早期に道路機能が確保される必要があ る. したがって盛土構造も耐震性が求められるが, 既設盛土は効率的かつ合理的な照查手法がない. 本論 文の評価手法の骨子は, 盛土基本情報の評価点法による一次評価, 変形量の簡易予測図による二次評価, 復旧土量から算定する許容変形量の設定から成る。この手法を用いて過去の被災区間や実際のモデル路線 で適用し，実際の路線においても評価対象箇所の合理的な抽出が可能であること，復旧体制の規模によっ て目標時間内での復旧可否が判断可能である等の手法の有効性を確認した。これらより対象盛土の選定か ら残留変形量の算出, 許容変形量の設定等を体系化した合理的で実務的な手法を構築した.
\end{abstract}

Key Words : disaster management, embankment, earthquake, seismic assessment, expressway

\section{1. はじめに}

高速道路会社（以下，「NEXCO」という。）が建 設・管理する高速道路における盛土の設計は，建設発生 土を有効利用し，降雨や交通荷重等の厳しい外的作用に 対し，十分な安定性を有し，恒久的かつ経済的なものと することを基本としている.この設計方針で施工された 盛土は，これまでの経験をもとにした標準法面勾配や盛 土材料の締固め基準の設定圣を行い，これらを踏まえた 適切な排水処理や良好な品質・施工管理を行うことによ り安定性が確保できる.

地震の大きな外力に対して盛土は, 橋梁等の構造物に 比べて修復性がよく, ある程度の地震被災においても早 期復旧が可能であるという特長がある．また，平成7年 に発生した兵庫県南部地震における盛土の被害”につい ても, 構造物の取付部の段差, 切り盛り境部における舗 装のクラック, 盛士路肩部の陷没等, 比較的軽微な被害 に止まっているため, 地震時の安定性はある程度確保さ れていると考えられる.

しかしながら，平成16年に発生した新潟県中越地震 （図-1），平成19年に発生した新潟県中越沖地震，高速 道路の被害ではないが能登半島地震では，大きな地震力
や降雨の影響があったことも一因ではあるが，他の構造 物に比べて盛土の被害が顕著であった ${ }^{3,4,5)}$ ，また，平成 21年に静岡県の駿河湾沖で発生した地震では, 東名高速 道路の牧之原SA近くのぜい弱岩を盛土材料に用いた盛 土が被災したの゙。当該箇所の復旧には5日間を要し，お盆 直前の交通規制が利用者に与える影響は多大であった。 この地震での大きな盛土崩壊は一箇所ではあったが，高 速道路は, 橋梁や土工等を含めて “線” として機能が必 要で, それには, 盛土においても早期に交通が確保でき ることの重要性が再認識された. さらに平成23年の東北

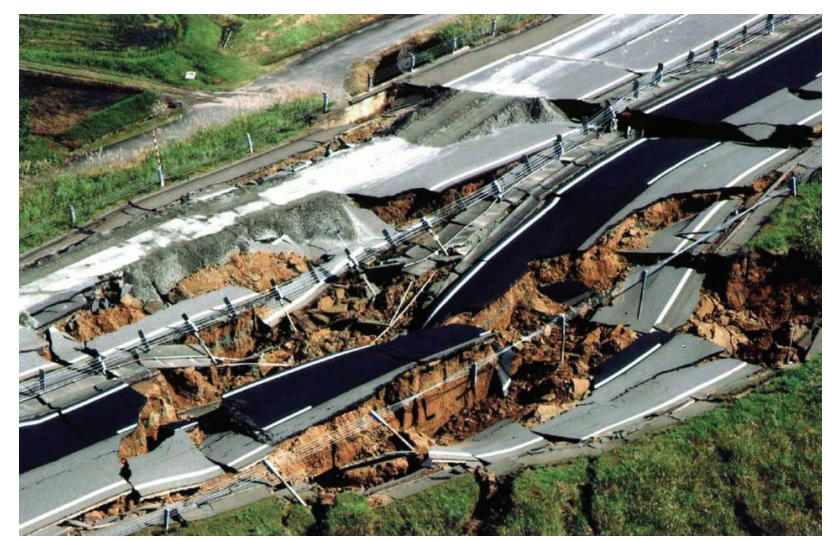

図-1 中越地震における高速道路の盛土被災 
地方太平洋沖地震では, 地震の規模の大きさもあって, 高速道路の被害は盛土部が多くかつ広範囲であったが, そのほとんどが軽微な路面のひび割れ，段差程度であっ た. NEXCOは地震発生約20時間後には利用者の誘導, 保護, 道路点検, 応急の簡易補修を終え緊急車両を通行 可能にした. 高速道路が被害の甚大な被災地一の救助, 復旧等の支援路として東日本地区一の動脈を確保した》。 しかしながら，すべての路線が一般車も通行できる高速 道路としての利用上の機能を確保するまでは21日間を要 した.

このような被害実態に対し盛土の而震性能の議論は, 平成12年に「土木構造物の而震設計法等に関する第三次 提言 (土木学会) ${ }^{8)}$ 」では, 土構造物についてもこれま で以上に而震性の確保が必要なこと, 大規模地震動（レ ベル2地震動）を想定した設計を考慮する必要があるこ と等が提言されている．また，鉄道施設では，平成11年 に大規模地震動の設計を取り入れた鉄道構造物等設計標 準（耐震設計） 9)が策定され，港湾施設10)，河川堤防 ${ }^{11)}$,

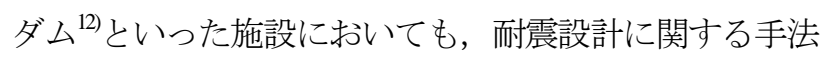
が定められている. 高速道路あり方検討有識者委員会で

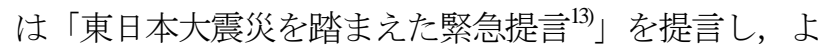
り高い盛土の耐震性が課題であるとした。これらと NEXCOの事業継続計画 ${ }^{14} の$ 必要性等とあいまって, 盛 土においても地震時に早期の機能確保が求められている. 高速道路事業者のNEXCOにとって, 地震災害時の緊急 交通路の確保, 早期開通は復旧, 経済の観点からも社会 の要請であり，それに応えることは社会的な責務である。 このような災害時の対応は, 高速道路事業者における災 害マネジメントの一環であるといえる.

災害マネジメントでは災害想定，事前対策，災害後対 策, 時間軸を持った復旧対策の各段階での対応が必要と なる. ソフト面の対応は，防災訓練による情報収集や復 旧検討のための組織行動訓練や，関連行政機関等との災 害協定の締結，災害時の事業継続計画を策定を行ってい る. ハード面の対応は，橋梁では耐震補強対策を行って 効果をあげている. 他方で, 高速道路としては “線” と しての機能が必要であり, このような耐震性は盛土にも 求められる機能である.NEXCOの盛土の耐震性評価に ついて, 平成11年度から平成15年度にかけて検討して きた ${ }^{15}$ 。この中で, 地震時における土構造物の安定性を 変形量で評価する設計体系を提起し, 変形量を照査する 而打震性評価手法を基本とした。この評価手法の内容は, その後の新東名建設で検証し ${ }^{10,177}$ ，平成21年に高速道路 建設時の高盛土における耐震設計として基準化した ${ }^{18)}$.

一方, 高速道路の既供用路線の盛土の而震性評価につ いては，管理する盛土延長が路線の約4割（約3,000km） で膨大にあることや，評価手法が明確でなかったこと等 から，積極的に検討，対策工はされてこなかった，しか
しながら，前述したように盛土の而震評価の必要性は高 まっており，盛土を何らかの方法で評価するといったこ とが重要であり，筆者らはこれまでに幾つかの検討を行 ってきた ${ }^{19,20)}$.

本論文は，高速道路の既設盛土を対象としてその耐震 性評価手法について述べるものである，既設盛土の地震 災害マネジメントは，復旧目標（復旧レベルや復旧時間 等) の設定, 盛土の耐震性能の評価, 被害に対して復旧 に要する人員や資材・機材を想定し復旧目標を達成でき るかの評価，達成できない場合はその対策，また，盛土 に必要な而震性を機能保持するための日常的・定期的な 点検や排水施設等も含めた補修等から成る. さらに, こ れに加えて災害時の組織体制や日常的な管理段階での点 検体制や維持補修等の災害事前事後の組織対応があるが, これらのうち，本論文では復旧目標の設定から復旧目標 を達成できるかの評価までを対象としている.

既設盛土の評価手法を検討寸るにあたり，全延長にわ たって1箇所毎に安定性を計算手法によって評価するの は現実的ではない，宅地造成等では，安定検討を行う箇 所を選定するスクリーニングという手法を用いて，対象 とする箇所を選択している ${ }^{21)}$. 道路盛土ではスクリーニ ングの方法等いくつか提案 2)されているが，対象盛土の 選定, 安定性の評価手法, 許容值の設定等を体系的に定 めた手法はない，そのため，本論文での手法は下記を基 本的な考えとし，それらを実現するための課題に対して 検討した.

1) 延長約 $3,000 \mathrm{~km} も の$ 盛土に適用できる比較的簡易な 手法であること.

2) 対象盛土の選定, 許容值の設定, 安定性の評価に至 る一連を体系的にまとめた手法であること．

3）評価手法を利用寸るのは，現場事務所の実務の技術 者を想定する. 土工に関する一般的な技術を要する 者であれば，誰でも実施できる合理的かつ簡便な方 法であること.

4) 対象盛土の選定では，評価者でのばらつきがでない ように，既存の盛土の高さや地形条件等の基本条件 を基に点数化すること.

5）耐震性照查は変形量での照査を行うこととし, 許容 残留変形量は, 復旧可能作業量を考慮した復旧シナ リオに基づくものであること.

以上のように，既に供用している高速道路盛土が，地 震発生後にきわめて早期に機能復旧できることを念頭に, 実務性を考慮した検討を行ったものである. これらの具 体的な検討を行い, 既設盛土の耐震性評価手法を構築し, また，この手法を実際の路線をモデルに適用して，その 能力を検証した. 


\section{2. 地震時における盛土の復旧目標と要求性能}

地震時における盛土災害の影響度を評価する上では, 第一に災害時の復旧時間及び目標復旧レベルを設定する 必要がある.これは事業継続計画を策定していくにあた っての前提を設定することである ${ }^{23)}$. 国土交通省では首 都直下地震応急対策業務において, 広域支援部隊の進出 ための緊急輸送ルートである最低限の緊急輸送基盤の確 保を 1 日間としている ${ }^{24)}$. したがって，本検討において も高速道路の緊急復旧まで期間は，1 日以内であると設 定した.

地震における盛土に必要な性能は，想定される地震 動に対して, 高速道路に求められる機能, 安全性, 供用 性，修復性の観点から設定した。したがって，供用期間 内に発生する確率が高い地震動（レベル1地震動）に対 しては，地震後に軽微な補修程度で速やかに機能回復が 可能となるような耐震性能（具体には，路面クラックや 段差等速やかに修復可能な軽微な損傷）を設定した．ま た，供用期間中に発生する確率は低いが大きな強度をも つ地震動（レベル2地震動）においては，盛土を軽微な 損傷に留めることは困難な場合もあることから，地震後 に残留する塑性変形をある程度許容し，短期間に修復可 能となるような而震性能を設定した。

\section{3. 本耐震性評価手法の手順}

道路盛土の調查・点検や対策後の評価等は道路防災総 点検等で, 実施手順が示されているものの, 而震性も含 めた評価を体系化したものはない，そこで本而震性評価 手法では, 従来の調查・点検に耐震検討箇所の抽出と変 形量の確認を含めて図-2に示寸手順で行うことした.

手順は，道路延長に対して相当量の盛土箇所があるこ とから，盛土形状，現地条件，人家や土地利用等の周辺 条件及び，地盤条件を考慮し，重点盛土の抽出（而震性 一次評価）を行った上で，而震計算等により残留変形量 を算定し耐震性能照査（耐震性二次評価）を実施し評価 する手順とした. この時, 道路周辺施設への影響の有無, 目標とする復旧レベル，事前・事後対策の仕分け等につ いて勘案した上で, 総合的な而震性の評価を行うことと した. 以下各手順の要旨を示す.

\section{a) 既存資料による机上調査の項目}

平面図や横断図, 地形図, 地質図等の各図面, 各土質 調查報告書，施工時の工事品質管理データ等の資料より， 机上で対象盛土の抽出に必要なデータの整理を行う.

\section{b) 点検結果等による現地調査の項目}

日常点検や定期点検, 道路防災点検等, 現場の点検結 果等の資料より, 対象盛土の抽出に必要な情報を得る.

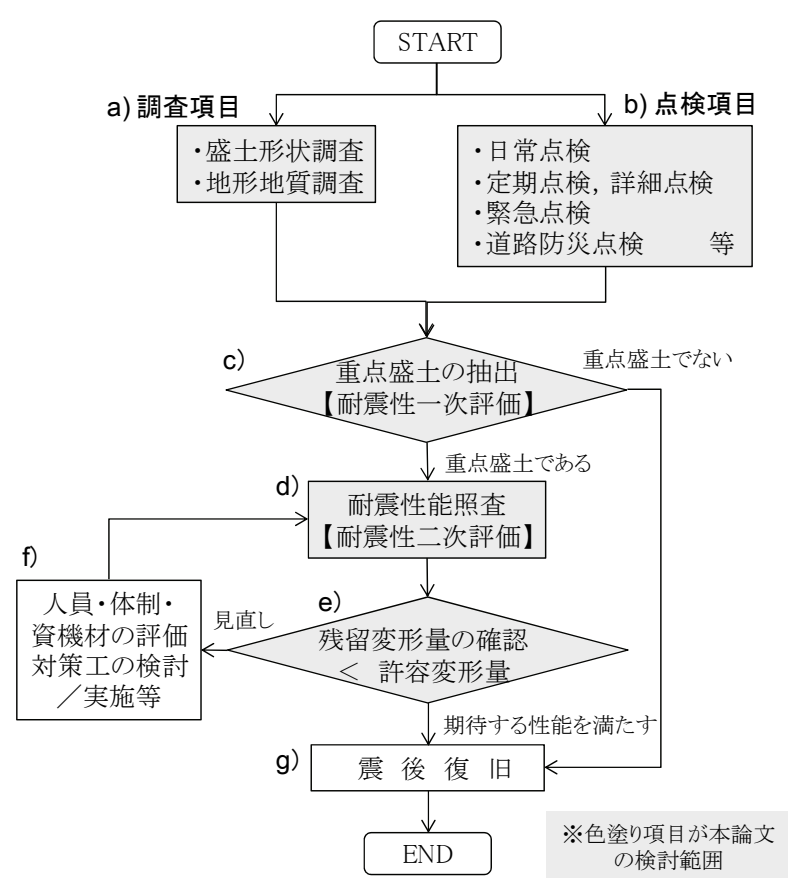

図-2 本而震性評価法の手順

\section{c）重点盛土の抽出【耐震性一次評価】}

a), b)の既存資料や点検結果から, 調査項目を整理し, その項目を評価することによって重点盛土の抽出を行う.

d) 耐震性能照査【耐震性二次評価】

c)で抽出された重点盛土に対して, 安定計算等の手法 により耐震性能の照查を行う.

\section{e) 残留変形量の確認}

地震時における盛土の残留変形量を算出し, 設定した 許容変形量との比較を行う. 総合的な判断により期待す る性能を満たしているか確認する.

\section{f） 人員・体制・資機材の評価，対策工}

e)で見直しが必要となった場合，対象とする路線での 復旧体制（人員・資機材等）の評価を行い，場合によっ ては体制強化等の対策を講ずる．また，詳細調査の実施， 詳細手法による安定性評価, 水抜き工等の対策工を実施 し, 再度d)而震性能照查を行う。

\section{g）震後復旧}

地震発生時には事前に想定した比較的軽微な損傷の復 旧を行う。

なお，図-2には本論文における検討範囲を着色で示し ている，a)〜c)については論文の5章及び6章，d)につい ては7章，e)については8章，a)〜e)までの手法の検証を9 章に示寸.

\section{4. 対象となる重点盛土抽出方法の検討}

既設盛士の耐震性を検討寸る場合, 路線全域の個々の 


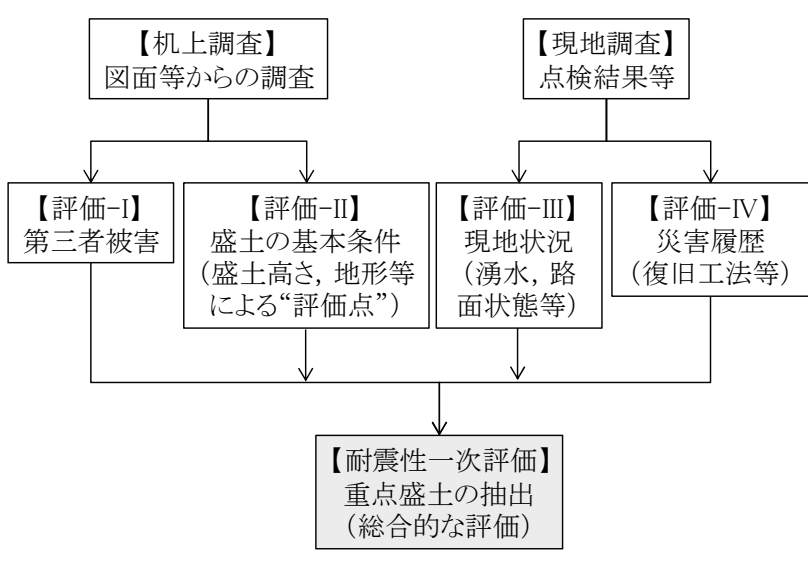

図-3 重点盛土の抽出（而震性一次評価）の概念

断面に対して検討することは，盛土箇所が膨大な量のた め, 検討に要する時間や経済性の観点から現実的ではな い，したがって，まずは路線の数ある盛土の中から，耐 震性評価の対象となる重点盛土の抽出方法を検討した. この重点盛土の抽出をここでは「而震性一次評価」と位 置づけした.

耐震性一次評価は，図-3 に示寸ように図面等から判 断できる机上調査と, 現地の点検結果等から判断される 現地調査に大別できる。ここでは，而震性の一次評価は， 既往文献等 $25,26,27$ の評価項目等を整理し，比較的簡便な 手法を検討する上で有効であると判断した項目とし（表 -1），それぞれを評価した上で総合的な評価により抽出 する方法とした．以下に本手法の評価項目を示寸.

\section{a) 第三者被害に関する項目【評価-】}

災害が発生した場合の第三者への被害可能性の有無で 評価する項目．これに該当する箇所は，崩壊の可能性が それほど高くない箇所でも，被害が発生した時の影響の 大きさから，対策検討の優先度が高い箇所と判断し，盛 土構造や現地条件に関わらず重点盛土として抽出するよ うに設定した。

\section{b) 盛土の基本条件に関する項目【評価-川】}

盛土の構造や地形・地質等の盛土基本条件により分類 する項目，これらは，既存の図面等，管理用の資料から 抽出整理できる情報（机上の情報から抽出整理できる情 報）である．盛土の基本条件から，潜在的に地震の被害 を受けや寸いと想定される盛士箇所を，“点数化”によ り抽出する手法とした.

\section{c）現地条件に関する項目【評価-III】}

盛土における湧水，法面・路面の変状及び排水施設の 状態により評価する項目. 常時の点検等で変状等が見ら れる箇所は，地震時にも不安定となる可能性が高いもの と判断し，評価対象として設定した．現地状況としては, 日常点検, 定期点検, 詳細点検, 緊急点検等の各点検結 果を活用する.
表-1 各評価手法と本手法における評価項目

\begin{tabular}{|c|c|c|c|c|c|}
\hline 評価手法 & 地形条件 & 地盤条件 & 盛十条件 & 変状履歴 & 現地条件 \\
\hline $\begin{array}{l}\text { 道路震災対 } \\
\text { 策便覽(震前 } \\
\text { 対策編盈) }\end{array}$ & $\begin{array}{l}\text { 地山勾配 } \\
\text { 集水地形 }\end{array}$ & $\begin{array}{l}\text { 軟弱性 } \\
\text { 地下水位 }\end{array}$ & $\begin{array}{l}\text { 盛土材 } \\
\text { のり面勾配 } \\
\text { 橋梁取付 }\end{array}$ & $\begin{array}{l}\text { 被災履歴 } \\
\text { 改良復旧 }\end{array}$ & \\
\hline $\begin{array}{l}\text { 盛土のり面 } \\
\text { の緊急点検 } \\
\text { 要領(案 })^{26}\end{array}$ & 集水地形 & & $\begin{array}{l}\text { 盛土材 } \\
\text { 盛土高 }\end{array}$ & & $\begin{array}{c}\text { 湧水 } \\
\text { 路面変状 } \\
\text { のり面変状 }\end{array}$ \\
\hline $\begin{array}{l}\text { 国土交通省 } \\
\text { 新道路技術 } \\
\text { 会議 }\end{array}$ & 地山の形状 & & $\begin{array}{l}\text { 土質 } \\
\text { 施工 } \\
\text { 盛土構造 } \\
\text { 盛土高 } \\
\text { 車線幅 }\end{array}$ & 補强構造 & 排水処理 \\
\hline $\begin{array}{l}\text { 本手法に } \\
\text { おける項目 }\end{array}$ & \multicolumn{3}{|c|}{$\begin{array}{c}\text { 盛土の基本条件に } \\
\text { 関する項目 } \\
\text { 【評価-I】 }\end{array}$} & $\begin{array}{c}\text { 現地条件に } \\
\text { 関する項目 } \\
\text { [評価-III] }\end{array}$ & $\begin{array}{l}\text { 災害履歴や } \\
\text { 復旧履歴に } \\
\text { 関する項目 } \\
\text { 【評価-IV】 }\end{array}$ \\
\hline
\end{tabular}

\section{d) 災害履歴や復旧履歴に関する項目【評価IV】}

過去の災害履歴や復旧工の実施有無により評価する項 目．過去の災害履歴がある箇所は，今後発生する地震時 にも不安定となる可能性が高いものと判断し，災害履歴 の有無を評価対象とした．ただし，強化復旧等対策を講 じている箇所は除く.

「評価-II 盛土の基本条件」については，現場技術者 が効率的，特別な技術的な判断を必要としない，かつ評 価者によってのばらつきが生じないように，評価点を設 けて評価する「評価点法」を採用した。この評価点法は, 技術者の経験による重み配分ではなく，重み付けの根拠 が明確になるように，客観的かつ定量的なデータを用い て，既往の震災経験を統計分析した簡易判定法である. この判定法の詳細は第 5 章, 6 章に述べる.

\section{5. 盛土の基本条件による一次評価手法の検討}

\section{(1) 検討方法}

\section{a) 検討の基本}

「盛土の基本条件」の検討にあたっては，高速道路の 盛土被害が顕著であった新潟県中越地震の関越自動車道 の被災箇所の図面や被災記録を基に行った。この事例を を対象としたのは，これまでの大規模地震で高速道路の 盛土が何か所も崩壊するような事例が中越地震のみであ ったためである。 なお，一般道路における盛土被害は他 の地震でも報告されているが 5)，高速道路と盛土品質管 理基準や施工機械が異なるので対象としていない，した がって，他地域の場合での適用性や海溝型地震の場合の 事例を検討していないが，高速道路の建設当初から初め て大きな盛土被災を受けた地震としては中越地震の事例 は重要で, 本手法ではこの事例を対象とした検討を進め ることとした，検討手順を図-4 に示す．各種図面や被 


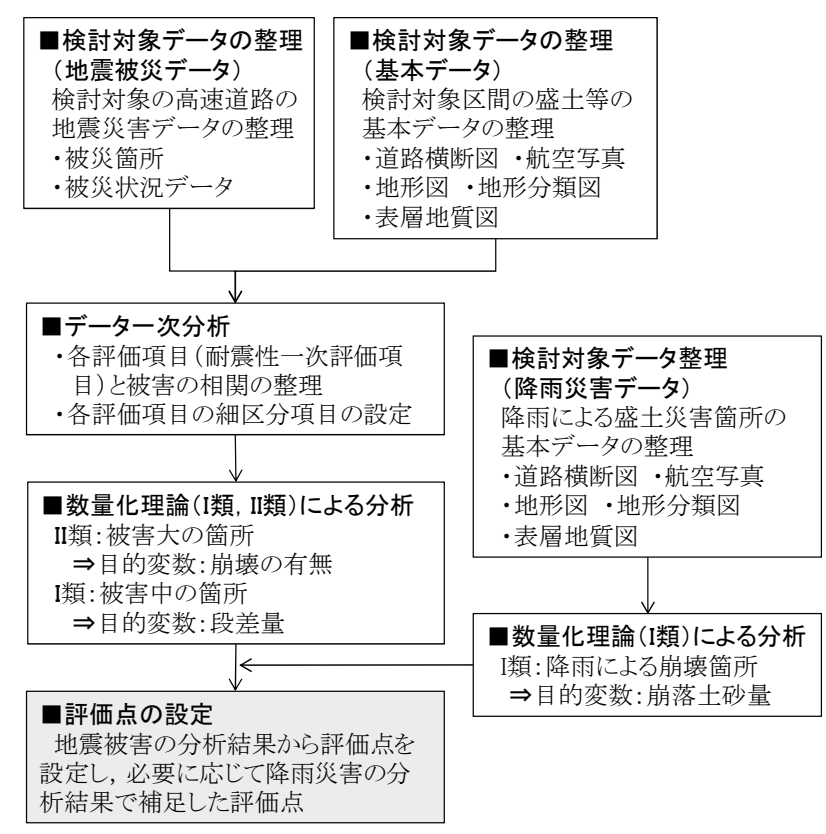

図-4 盛土の基本条件による一次評価法検討の流れ

災記録から盛土基本情報をデータベース化，また，各評 価項目ごとのデータ分析し, 数量化理論による分析を行 った.

\section{b) 検討の対象}

本検討では新潟県中越地震時の関越自動車道の地震被 害データを基に，地震被害に関連する要因の程度を定量 的に分析するため, 数量化理論を用いて各項目(要因)別 に評価点の設定を行った. また，この評価点は降雨災害 データの分析結果も考慮して設定した．検討対象は，

2004 年新潟県中越地震において被災した関越自動車道 の盛土区間（堀之内 IC〜長岡 IC 間延長約 32km）とした. 本区間において，道路の横断図が作成されている $20 \mathrm{~m}$ 間隔ごとに盛土基本条件（盛土高・地盤傾斜角・構造物 の有無等）のデータベースを作成し，このデータベース を用いて被災の程度を記入し各要因の評価点を設定した。 ここでいう構造物の有無とは，対象とする横断面にボッ クスカルバート等の構造物が含まれているかをいう。こ のように, 被災事例の分析には, 「数量化理論 I 類, II 類」を用いた数值的な根拠を基に，地震被害に影響を与 える各項目の評価点を設定した.

\section{c）盛土基本情報のデータベース化}

$20 \mathrm{~m}$ 間隔の盛土の横断図から図-5に示すように基本条 件(盛土高，地盤傾斜角等)及び地形分類，表層地質分類 を読み取り，表-2 のように路線全体のデータベース化 を行った．このとき，地形・表層地質の読夕取りには， 国土交通省の HP より入手できる 1/50,000 地形分類図, 表層地質分類図 ${ }^{28}$ を用いた．対象区間では 1,106 箇所 (断面)の盛土をデータベース化した.

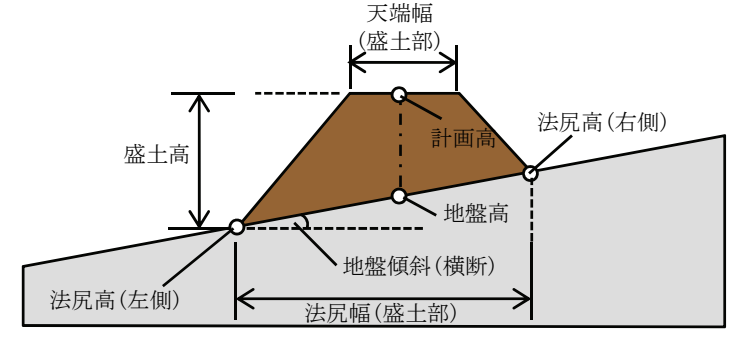

(a) 横断図からのデータ読み取り

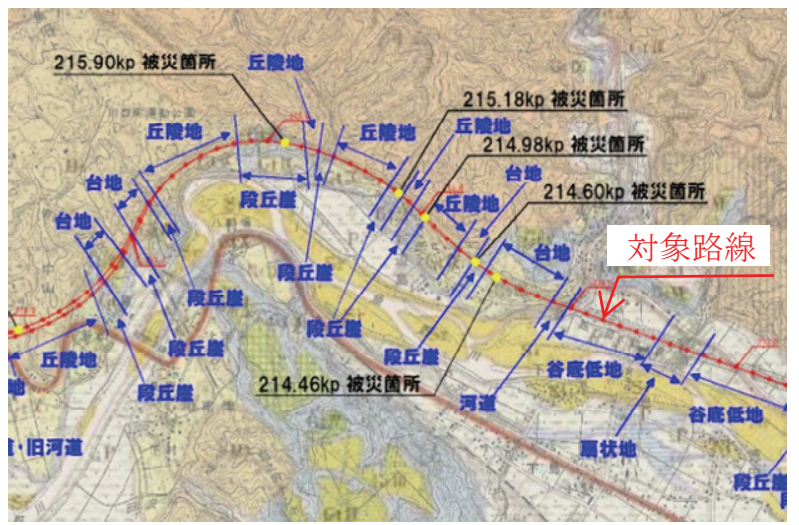

(b) 地形分類図からのデータ読み取り

図-5 各図面からの盛土の基本情報の読み取り

表-2 データベース化した盛土基本情報

\begin{tabular}{c|l}
\hline 項目 & \multicolumn{1}{c}{ 基本情報 } \\
\hline \hline 盛土諸元 & $\begin{array}{l}\text { 盛土高, 地盤傾斜（横断方向）, } \\
\text { 地盤傾斜（縦断方向） }\end{array}$ \\
\hline 盛土形式 & 両盛土, 片盛土, 片切片盛土等 \\
\hline 地形分類 & 台地, 段丘崖, 扇状地, 谷底低地等 \\
\hline 表層地質 & 段丘堆積物, 扇状地堆積物, 河床堆積物等 \\
\hline
\end{tabular}

\section{d) 被災状況と被災程度}

中越地震の関越自動車道の被害は，図-6に示す区間 で3つの形態に分類できる ${ }^{29}$. タイプ 1 は山間部におけ る緩やかな傾斜地盤上の盛士崩壊等の被災，タイプ 2 は 比較的良好な地盤上のボックスカルバート部等での段差 被害, タイプ 3 は軟弱な地盤上のボックスカルバート周 辺の盛土の被災である.

本検討ではこのような被災状況をさらに詳細に測点ご とに整理し，データベース上では同範囲内での被災箇所 の被災程度を大，中，小の 3 つに区分した．被災度[大] は盛土のすべり崩壊が走行車線にまで達している状況で, このような盛土の崩壊が生じた場合は，想定する復旧期 間内での緊急交通路の確保が困難と考えられる事象であ る. 被災度[中]はボックスカルバート等の構造物背面の 盛土が沈下し, 路面の横断方向に段差が生じている状況 で，このような段差の場合，段差の大きさと段差発生箇 所数や発生箇所で，復旧作業における作業量や作業時間 が増減し，1 日以内という目標時間内に復旧できるかの 


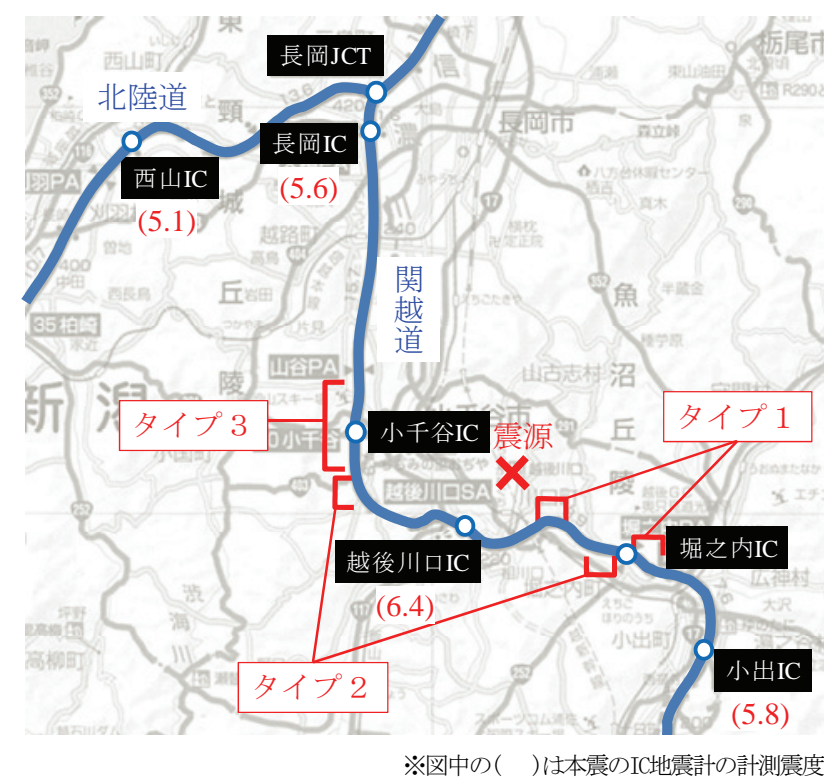

図-6 中越地震における関越道の主な被災区間とタイプ

判断に影響する事象である. 被災度[小]は損傷箇所が法 面又は法肩までに止まり走行車線まで達していないもの で，緊急車両の通行には支障のない程度の損傷である.

ここでは，一次評価において抽出すべき盛土は，図-7 に示すような車両の通行性に支障をきたすと考えられる 被災程度[大]もしくは[中]の箇所であると判断し，これ らの被災箇所を分析の対象とした． 検討では横断面 $20 \mathrm{~m}$ 間隔にデータベース化をしているので, 被災箇所数は被 災断面数としている. 被災度[大]は23箇所（崩壊箇所： 6箇所），被災度[中]は 68 箇所であった.

なお，図-6 の括弧内の数字は，高速道路 IC に設置さ れた地震計の本震の計測震度である. 震源に最も近い越 後川口 IC では計測震度 6.4, 小出 IC は 5.8, 長岡 IC は 5.6 である. 被災箇所の地震動は, 震源からの距離や地 形，地質等により異なり，一般的には地震被害分析にお いては，地震動の大きさも被害要因になると考えられる. しかしながら，本検討では，計測震度が 5.5 以上の大き な地震動が観測された範囲で特に被害が大きかった範囲 を対象としているので，地震動の大小による被害の大き さの影響は小さいと想定されることや，評価する盛土の 基本情報（地形分類や表層地質）により，ある程度盛土 個々の位置の地震による摇れ易さは評価できていると考 え, 地震動の大きさの項目は設けていない.

\section{(2) 数量化理論によるデータ分析方法}

\section{a) カテゴリー区分のための基本分析}

数量化理論での分析を行う前に, 数量化に用いるカテ ゴリーの区分を決定するために，被災状況と盛土高，地 盤傾斜角，地形等の各検討項目の関係を整理した. 図-8 に盛土高さと地艋傾斜角の関係を示す。ここでいう地盤

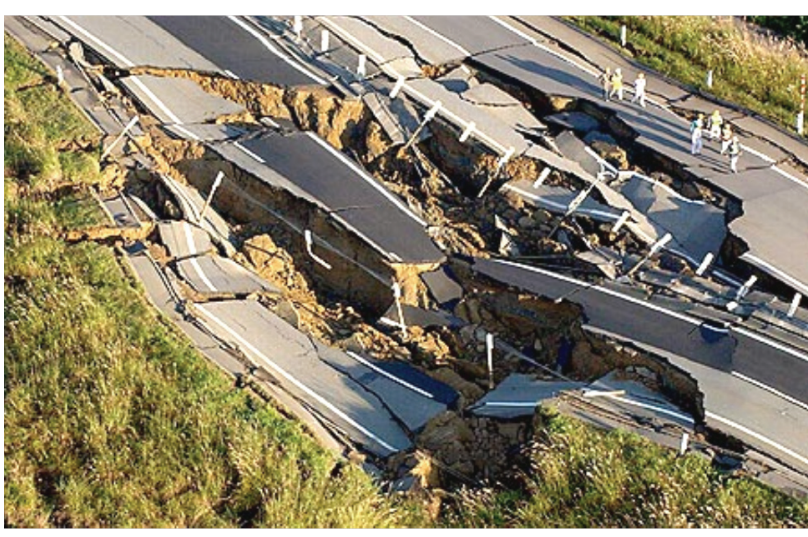

(a) 被災度大 : 走行車線まで及ぶ盛土崩壊

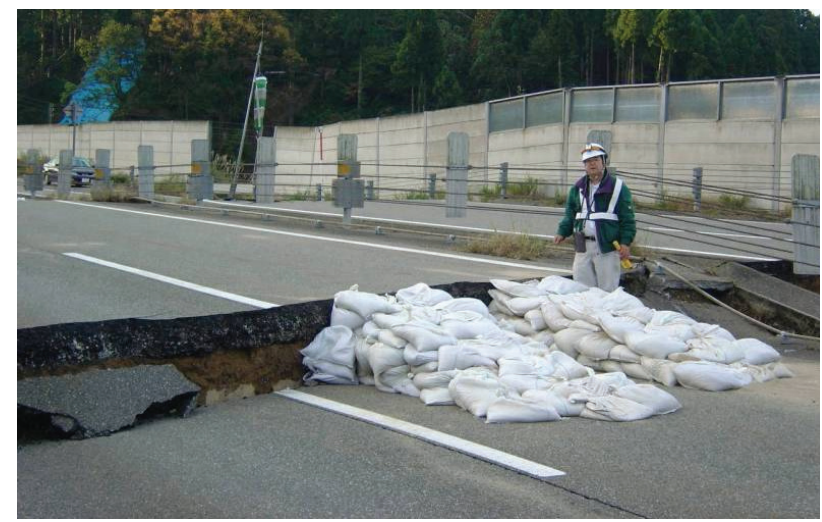

(b) 被災度中 : 走行支障を生じる構造物と土工部との段差

図-7 検討の対象とした被災度

傾斜角とは横断方向の傾斜と縦断方向の傾斜を合計した ものである.ここで，地盤傾斜を合計したことにより横 断方向のみの関係よりも被災との関係が明確になったた め，以後の整理では縦断傾斜との合計で示すこととした。 被災度[大]の箇所は，盛土高さでは 4 18m 付近に分 布しており，4m 未満には被災がない. 地盤傾斜角は 3 〜 17 程度に分布して，そのほとんどが $5^{\circ}$ 以上に分布 している. 被災度[中]は盛土高さでは 2〜14m 付近に分 布し，地盤傾斜角は $0 \sim 9^{\circ}$ 付近に分布している. 被災 度[大]と比較して，地盤傾斜角が小さく，そのほとんど は $5^{\circ}$ 以下に分布している. なお，盛土高さ 1 段(高さ $7 \mathrm{~m}$ 程度)と寸れば, 4 車線道路の盛土幅は約 $50 \mathrm{~m}$ である ので，横断傾斜 $5^{\circ}$ であれば盛土両端の法尻高低差は約 $4 \mathrm{~m}$ である.この結果より盛土が崩壊するような被災度 [大]と段差被害の被災度[中]は，地盤傾斜角 $5^{\circ}$ を境に区 分し, 地盤傾斜角 $5^{\circ}$ を境に, 被災形態が異なることか ら地盤傾斜の分類をして分析を行うこととした.

なお，地盤傾斜角の整理と同様に，地形分類と表層地 質分類についても整理したが，被災の程度との相関は小 さかったため, 要因として区分するが, 細かいカテゴリ 一の分類はせずに, 3 種程度に分類することとした．盛 土高さのカテゴリーについては, 高速道路の盛土 1 段高 さは標準では $7 \mathrm{~m}$ であるので, 盛土 1 段程度として $10 \mathrm{~m}$ 未満の区分を設けた。 また, 図-8に示すように高さ 


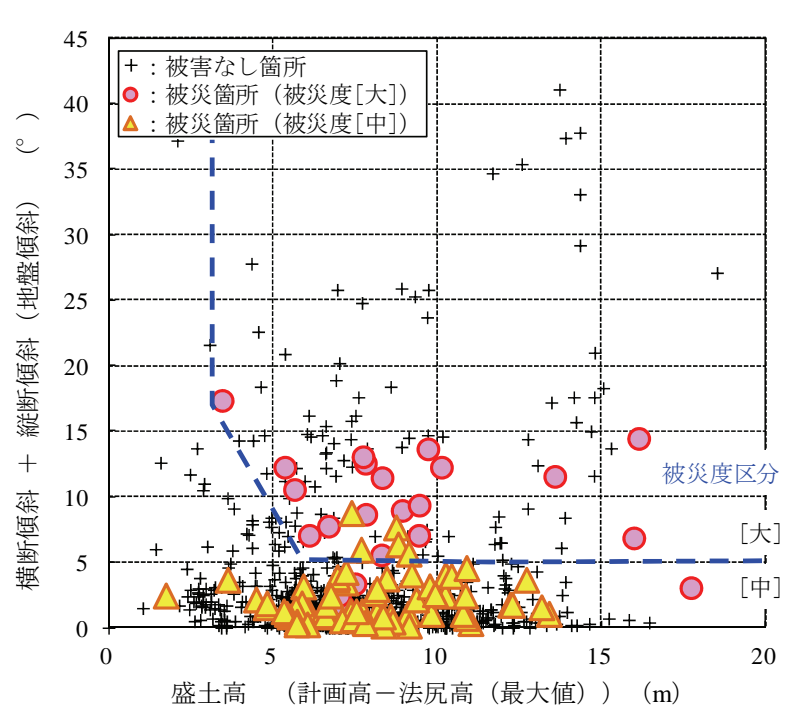

図-8 盛土高と地盤傾斜角

$15 \mathrm{~m}$ までのものが大半を占めることや，高速道路の設計 基淮 ${ }^{1)}$ では盛土高さ $15 \mathrm{~m}$ 以上を高盛土として分類し，排 水処理や安定検討手法を区分していること，さらに $30 \mathrm{~m}$ 以上は高さによる地震応答の影響が大きくなるとしてい るため, 盛土高さ $15 \mathrm{~m}$ 及び $30 \mathrm{~m}$ の区分を設けた.

\section{b) 数量化理論のデータ分析方針}

カテゴリー区分のための基本分析によって，地盤傾斜 角で区分可能であることが確認できた．したがって，数 量化理論に用いる場合, 全データを「平坦地盤上の盛土」 と「傾斜地盤上の盛土」とに区分した上で，分析を行う こことした．また被災形態が被災度[大]と被災度[中]で は異なるため, 表-3 のような数量化理論の分類を適用 した．被災程度[大]については，車線内に影響がある崩 落といった大きな損傷である. そのため, 被災の程度で はなく, 被災の有無を目的変数とした. 被災の有無は質 的な基準で示されるものであるから, 数量化理論 II 類 により分析した．被災程度[中]については，路面段差の 被害である. 段差の場合, その発生箇所数と段差の大き さが復旧時間に影響を与える要素であることから，量的 な基準である段差量を目的変数として数量化理論 I 類を 用いて分析した.

\section{(3) 数量化理論によるデータ分析結果}

\section{a) 平坦地盤上の盛土の分析}

被災程度[中]を対象として，目的变数を路面段差量と した数量化 I 類での分析を行った。 その結果を図-9 に示 寸. 変数として使用した要因(アイテム)は, 盛土高, 地 形分類, 表層地質, 地盤傾斜, 構造物の有無である. 各 アイテムのカテゴリーのスコアが高いほど，被災に関す る要因項目であることを示している．各カテゴリーをみ ると, 表層地質では, スコアの絶対数值は他のアイテム
表-3 数量化理論による区分

\begin{tabular}{|c|c|}
\hline 項目 & 基本情報 \\
\hline $\begin{array}{c}\text { 数量化理論 } \\
\text { 第 I類 }\end{array}$ & $\begin{array}{l}\text { 外的基淮が “量的” である. 相関関係を最大, } \\
\text { 又は予測誤差の } 2 \text { 乗平均を最小にする数量化. } \\
\text { 被災度[中]は土工と構造物の段差被害である. } \\
\text { 段差被害の大小により復旧時間も異なるため, 量 } \\
\text { で被害要因を区分する必要がある.したがって, } \\
\text { 路面段差量を外的基準にできるため, 数量化 I 類 } \\
\text { を用いる. }\end{array}$ \\
\hline $\begin{array}{c}\text { 数量化理論 } \\
\text { 第 II類 }\end{array}$ & $\begin{array}{l}\text { 外的基淮が “質的” である. 相対比を最大にす } \\
\text { る数量化. } \\
\text { 被災度[大]の場合は, 盛土が崩壊するような事 } \\
\text { 例で, 盛土被災の有無で区分できる. したがっ } \\
\text { て, 外的基準は質的になることから, 数量化 II類 } \\
\text { を用いる. }\end{array}$ \\
\hline
\end{tabular}

に比べて小さいが，カテゴリー内の分類では相対的に固 結度が低い地質ほどスコアが高くなっている，表層地質 がやわらかいと，地震動の影響も受けや寸く被災も大き くなると考えられるので, 被害傾向を適切に示している. 構造物の有無では, 構造物有りの場合のカテゴリースコ アが大きくなっており，これは他のアイテムに比べても 大きい. 図-6に示した被害分類でも平坦地盤は，構造 物部の被害が多くなっており, 被害傾向を適切に示して いるといえる，一方，盛土高さや地盤傾斜は盛土高さが 高くなるほど，地盤傾斜が大きくなるほど，盛土被害が 大きくなると考えられるが，その傾向とは異なっている. そこで，地震被害デー夕を補足するために，盛土被害と しては同種の事象であると考えられる降雨災害データを 用いて, 同様に数量化理論によって要因影響度の傾向を 確認した. 降雨災害データによる分析は c)で述べる.

\section{b) 傾斜地盤上の盛土の分析}

被災程度[大]文対象として，目的変数を災害の有無と した数量化 II 類での分析を行った．その結果を図-10に 示す.アイテムのカテゴリーのスコアが高いほど, 被害 に関する要因項目であることを示している．各カテゴリ 一をみると, 数量化 I 類での平坦地盤の分析と同様に, 表層地質，構造物の有無は，表層地質がやわらかいほど, 構造物が有るほど，カテゴリースコアが大きくなってお り，影響が大きい，ただし，盛土高さと地盤傾斜は傾向 が考えられる傾向と異なるため，a)と同様に降雨災害デ ータを用いてその傾向を確認した.

\section{c) 降雨災害データによる分析}

平坦地盤上の盛土及び傾斜地盤上の盛土で，数量化理 論による分析の補完として降雨災害データを用いた分析 を行った. 地震災害は湧水等が発生しや寸い地形条件や 盛土内水位等の水に起因寸るものが災害の一因になって いるといわれている. 同じく水に起因寸る災害として降 雨災害は，地震災害と同じような盛土の弱点箇所で発生 すると考えられる.このため, 盛土の弱点という意味で 


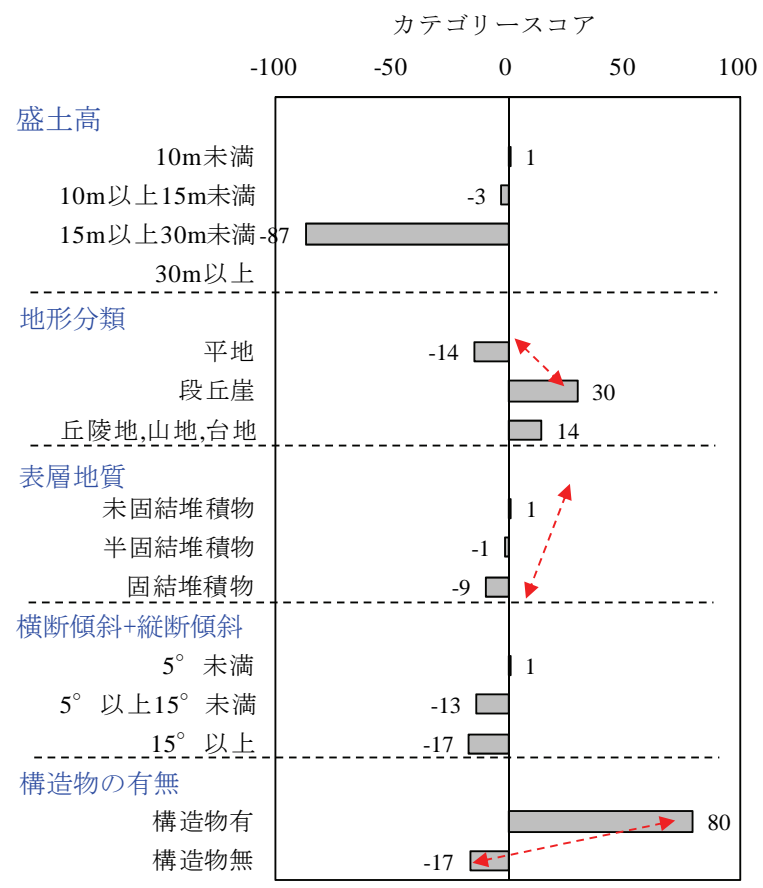

図-9 数量化理論類による被災度[中]の分析結果

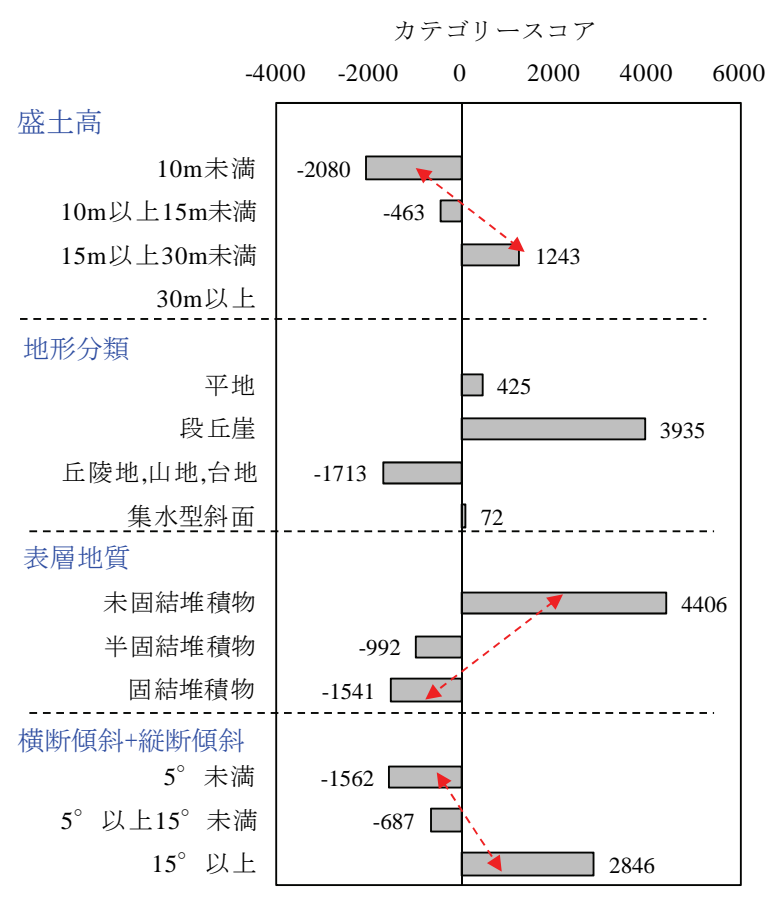

図-11 数量化理論I類による降雨災害の分析結果

は，同様に取り扱えるものと判断し，降雨災害データに ついて同様の分析（被災土量を目的変数とした数量化理 論 I類）を行い，補足データとして活用することとした. 検討に用いる降雨災害データは，NEXCO が保有する 平成 5 年〜平成 16 年の高速道路における災害発生時に 通行止等の車線規制が伴うもので，そのうち比較的災害 規模の大きなものを対象とした，本分析では，今回必要 とする地形・地質データや図面が揄っている 31 箇所の

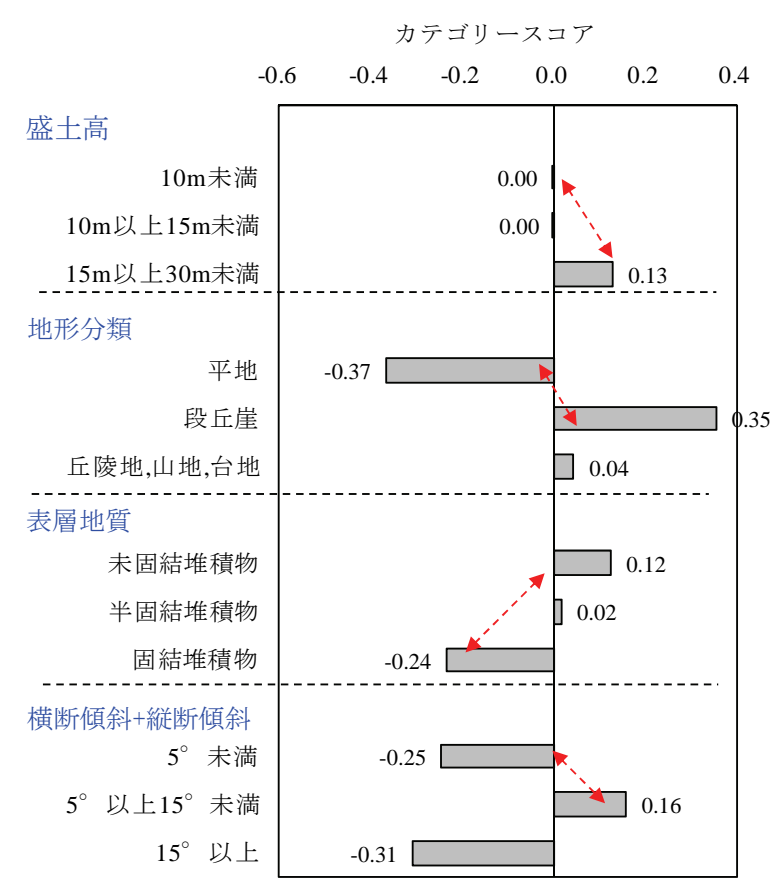

図-10 数量化理論I類による被災度[大]の分析結果

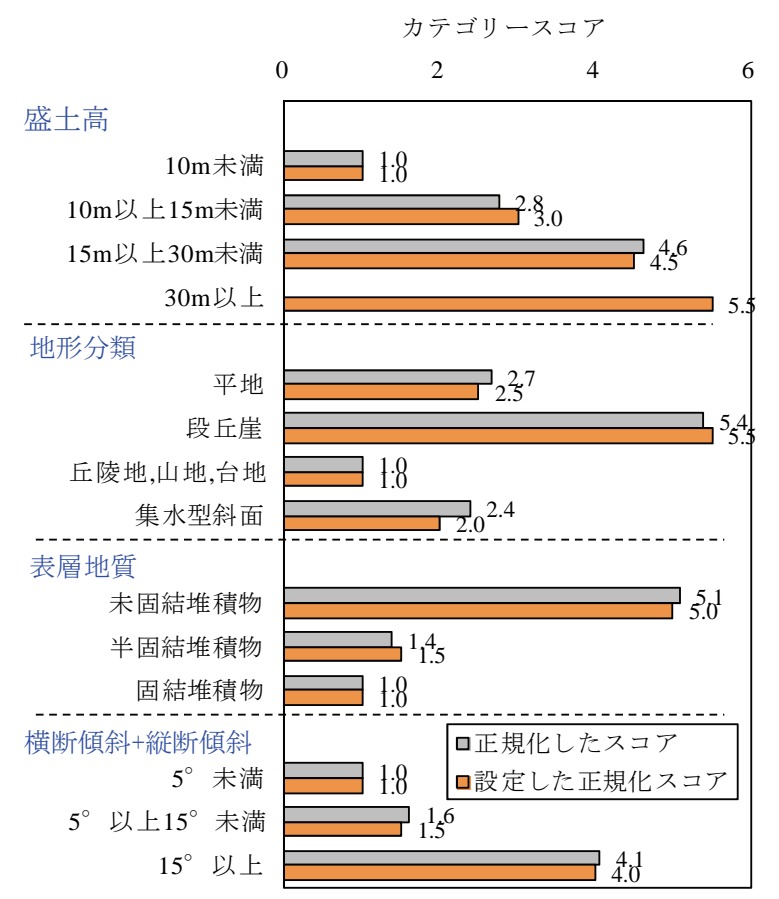

図-12 降雨災害の分析結果を正規化したスコア

災害データを用いた。 なお，降雨災害の場合，降雨量， 時期，地域は被災箇所各々で異なるが，地震災害に比心゙ てある一定の区間で多数の被害が生じるというよりは, 特定の箇所での被災であると想定される。したがって, ある豪雨による降雨量の条件よりも，降雨や地山からの 湧水に対しての盛土構造や地質や地形の影響が大きいと 考えたため，降雨強度の区分はしていない，また，被災 データは通行規制が伴う交通に影響が大きいものを抽出 


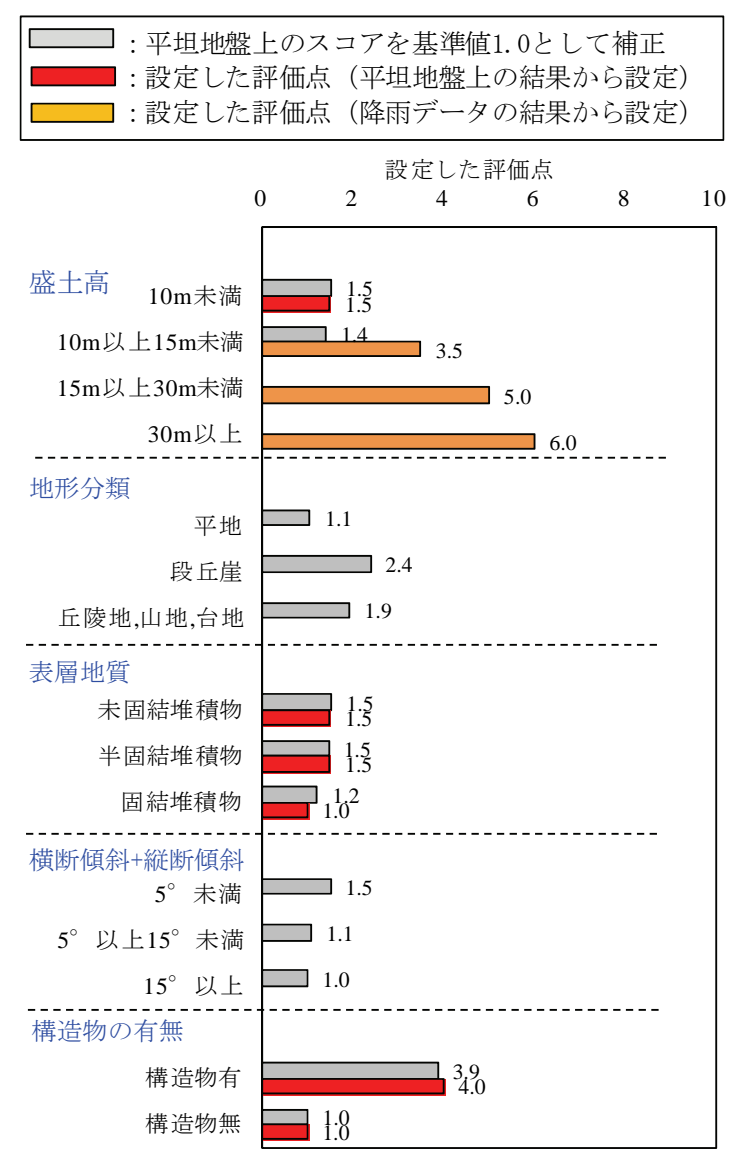

図-13 平坦地盤上の盛土の評価点

しており，地震被災のような被災程度の大中の区分はし ていない.

降雨災害データの数量化 I 類による分析結果を図-11 に示す．カテゴリースコアの大小はあるが，各アイテム とも，盛土高さが高くなる，表層地質がやわらかくなる， 地盤傾斜が大きくなると, 被災の影響度も大きくなって いる．なお，災害データでは盛土高さが $30 \mathrm{~m}$ を超える 高盛土が少なかったため, 盛土高さ $30 \mathrm{~m}$ 未満までの分 類とした。 しかしながら，山岳部の路線等では $30 \mathrm{~m}$ 以 上の高盛土も数多く存在するので区分が必要である。 そ のためデータ数や数量化理論としての検証に課題を残す が，ここでは図-12 に示すように 30m 以上の高盛土は, $30 \mathrm{~m}$ 未満のスコアを基に，カテゴリースコアを比例配分 することとした.

\section{d) 各項目の評価点の設定}

図-9, 図-10 の結果を各アイテム（盛土高など）ごと に，カテゴリー（10m 未満など）を相対的に比較し易い ように補正した. 補正の方法は各カテゴリースコアの最 小值を 1.0 として, その他の值は, 最小值を分母として スコアの值に応じて正規化した．降雨災害データの結果 も考慮して補正した結果が図-13，図-14である．この図 の評価点をさらに, 各評価項目の最大評価点の合計が 100 となるように配点し, 最終的に表-4 のように各評価

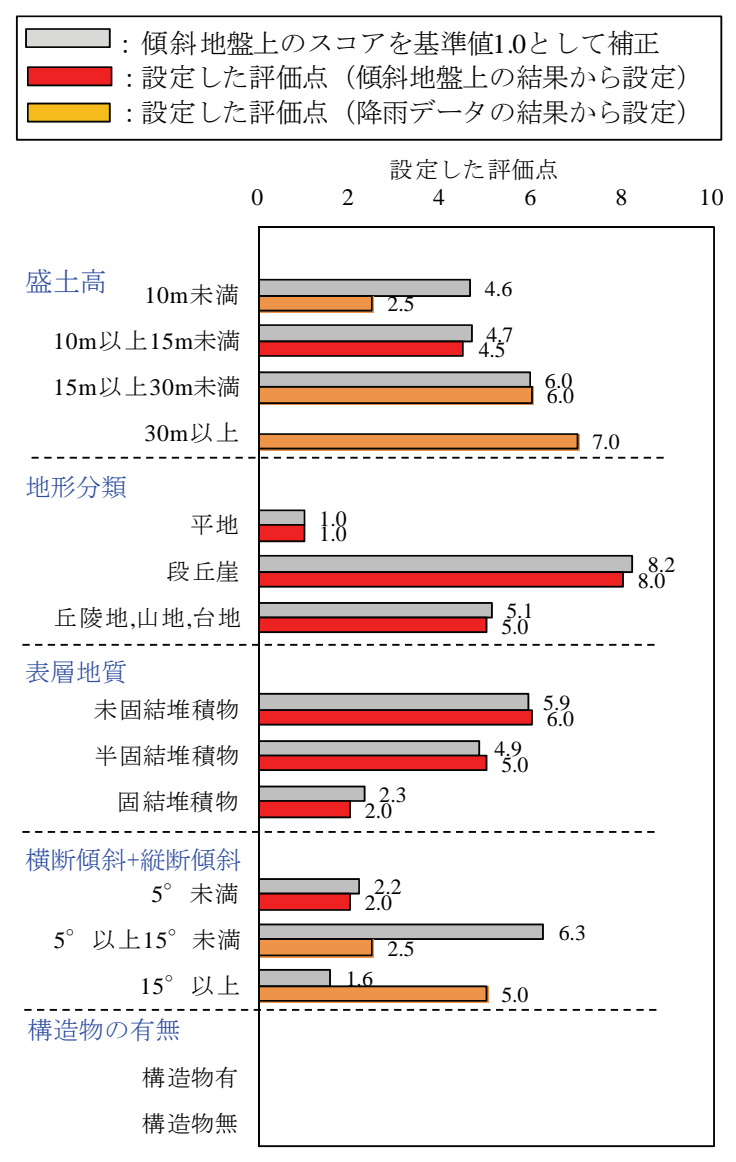

図-14 傾斜地盤上の盛土の評価点

点を設定した．評価としては，各項目における評価点を 合計し，その合計值が大きい程，被害が予測される盛土 で，耐震性を考慮する上での重点盛土となる.

なお，平坦地盤上の盛土における「地盤傾斜角」の項 目については，元々地盤傾斜角の小さい籄所のデータに 対する分析であるため，評価点の設定はしていない．ま た, 傾斜地盤上の盛土における「構造物の有無」の項目 については，ターゲットとした被災を被災度[大]の盛土 崩壊としたたので，被災はすべり破壊と考えられ被災モ ードに対して影響度が小さいものと判断し，評価点は設 定していない.

\section{6. 一次評価手法の適用性検証}

5.で検討した盛土基本条件による一次評価手法の適用 性を検証するため，検討した関越道の同区間で，同手法

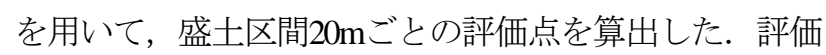
点の頻度分布をに図-15，図-16に示寸，図には被災の有 無を分類しているが，平坦地盤上及び傾斜地盤上ともに， 60点以上であればほとんどの被災箇所を抽出できる結果 となった．したがって，評価点から対象盛土を抽出する 閾值は60点と設定した。一部被災箇所であったにも関わ 
表-4 最終的に設定した各項目の評価点

\begin{tabular}{|c|c|c|c|c|}
\hline 項目 & 区分 & 区分の目安 & $\begin{array}{l}\text { 平坦 } \\
\text { 地盤 }\end{array}$ & $\begin{array}{l}\text { 傾斜 } \\
\text { 地盤 }\end{array}$ \\
\hline 盛土高 & $\begin{array}{l}10 \mathrm{~m} \text { 未満 } \\
10 \mathrm{~m} \text { 以上 } 15 \mathrm{~m} \text { 未満 } \\
15 \mathrm{~m} \text { 以上 } 30 \mathrm{~m} \text { 未満 } \\
30 \mathrm{~m} \text { 以上 }\end{array}$ & & $\begin{array}{l}12 \\
28 \\
40 \\
52\end{array}$ & $\begin{array}{l}10 \\
18 \\
24 \\
28\end{array}$ \\
\hline $\begin{array}{l}\text { 地形 } \\
\text { 分類 }\end{array}$ & $\begin{array}{l}\text { 平地 } \\
\text { 段丘崖 } \\
\text { 丘陵地,山地,台地 }\end{array}$ & $\begin{array}{l}\text { ·自然堤防, 河原, 旧河 } \\
\text { 道, 扇状地, 谷底平野 } \\
\text { • 段崖, 傾斜地盤, 沢横 } \\
\text { 断部等 }\end{array}$ & $\begin{array}{l}- \\
- \\
-\end{array}$ & $\begin{array}{c}4 \\
30 \\
20\end{array}$ \\
\hline $\begin{array}{l}\text { 表層 } \\
\text { 地質 }\end{array}$ & $\begin{array}{l}\text { 未固結堆積物 } \\
\text { 半固結堆積物 } \\
\text { 固結堆積物 }\end{array}$ & $\begin{array}{l}\text { • 河床堆積物, 扇状地堆積 } \\
\text { 物他 } \\
\text { - 段丘堆積物, 崖鍾地, 風 } \\
\text { 化岩, 軟岩(D級等 } \\
\text { - 軟岩 中硬岩, 硬岩等 }\end{array}$ & $\begin{array}{c}12 \\
12 \\
8\end{array}$ & $\begin{array}{c}24 \\
20 \\
8\end{array}$ \\
\hline $\begin{array}{l}\text { 横断傾 } \\
\text { 斜十縦 } \\
\text { 断傾斜 }\end{array}$ & $\begin{array}{l}5^{\circ} \text { 未満 } \\
5^{\circ} \text { 以上 } 15^{\circ} \text { 未満 } \\
15^{\circ} \text { 以上 }\end{array}$ & & $\begin{array}{l}- \\
- \\
-\end{array}$ & $\begin{array}{c}8 \\
10 \\
18\end{array}$ \\
\hline $\begin{array}{l}\text { 構造物 } \\
\text { の有無 }\end{array}$ & $\begin{array}{l}\text { 構造物有 } \\
\text { 構造物無 }\end{array}$ & & $\begin{array}{c}36 \\
8\end{array}$ & - \\
\hline
\end{tabular}

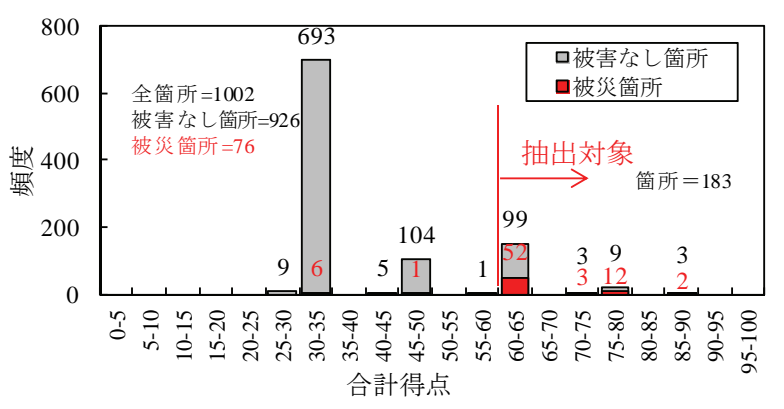

図-15 平坦地盤上の盛土の評価点頻度分布

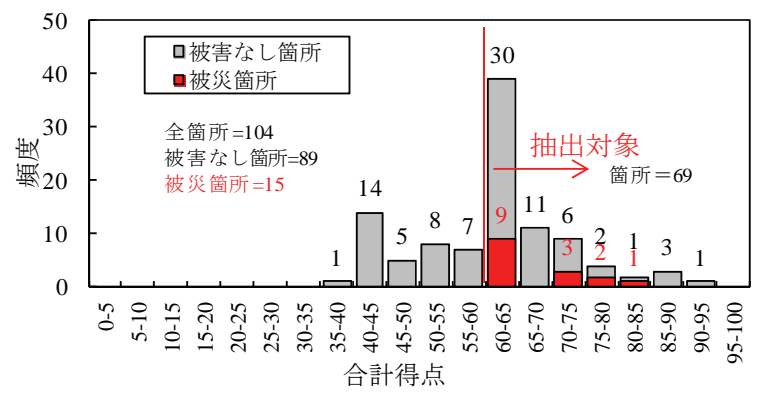

図-16 傾斜地盤上の盛土の評価点頻度分布

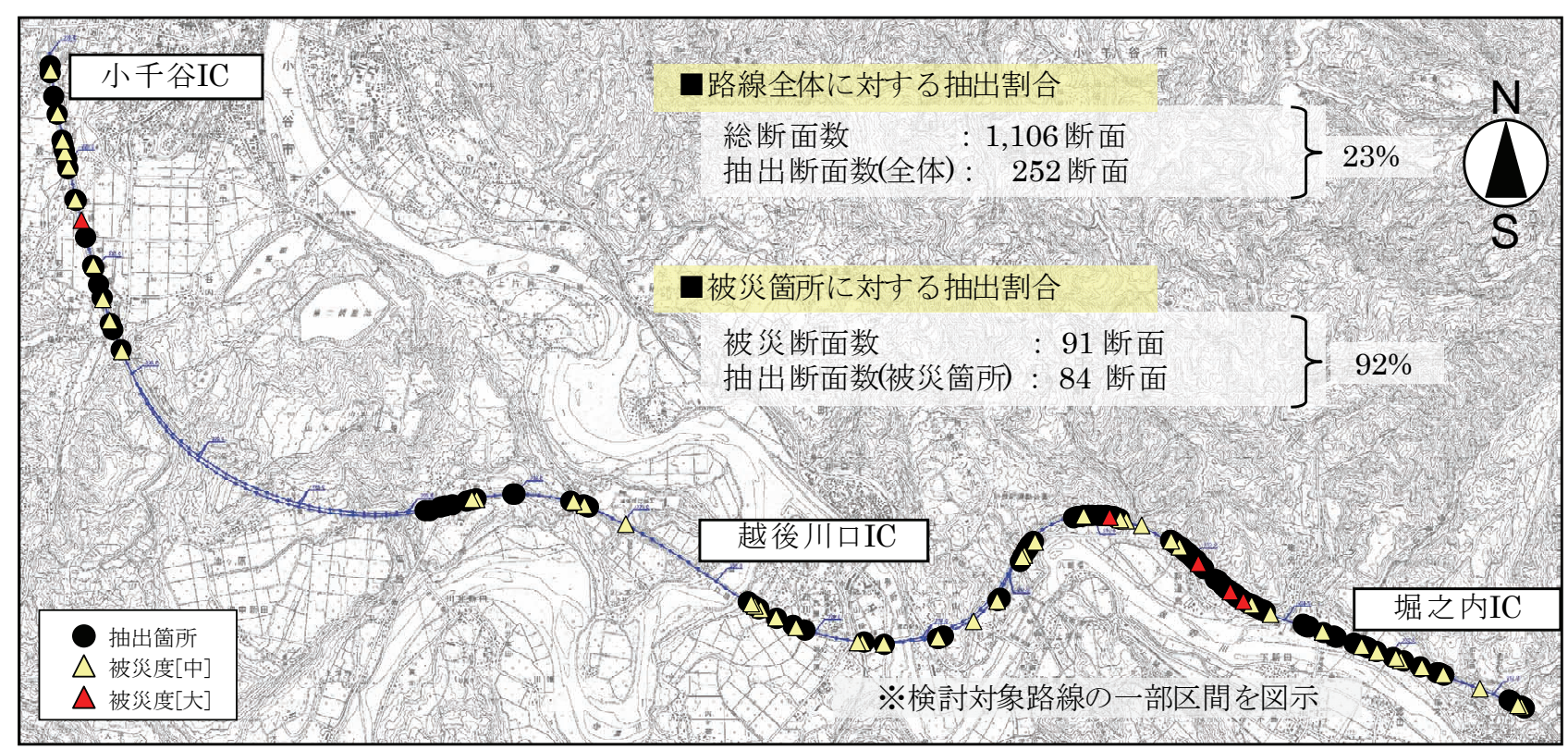

図-17 被災箇所と抽出箇所の位置

らず抽出できていない箇所が7箇所あるが，この箇所は 崩壊箇所の端部に位置する盛土であったり，摇すり込み 沈下により路面に波打ちが生じたが走行に支障のない程 度の事例である。したがって，評価点を用いた一次評価 は，閾值を60点とすることで地震時に大きな被害が発生 する可能性のある盛土を抽出できていると判断できる. なお，図-16の傾斜地盤上の盛土で抽出される盛土は, 被災していない箇所も多く抽出される課題を残すが，対 象盛土を抽出する一次評価としては見落としのないよう に，安全側の抽出になっているため，本検討では閾值60 点以上とした。
図-17に路線図に抽出された箇所と被災があった箇所 を示す．平坦地盤でボックスカルバート等の構造物が連 続する小千谷IC付近での抽出と，山間部で傾斜地盤の多 い越後川口IC〜堀之内IC間の抽出が多くなっている. 総 断面数が1106断面に対して抽出断面数は252断面となり 抽出割合は23\%となった．また，検討した評価点によっ て，概小全ての被災箇所を抽出できている（被災箇所全 91箇所のうち84箇所を抽出するため $92 \%$ の抽出）ことが 確認でき，ほぼ全ての被災箇所が抽出されることが確認 できた. 


\begin{tabular}{|c|c|c|c|c|}
\hline \multirow[b]{2}{*}{$\begin{array}{l}\text { 評価 } \\
\text { 手法 }\end{array}$} & \multicolumn{4}{|c|}{ 検討段階や現地条件に応心゙て, 評価方法を選択 } \\
\hline & $\begin{array}{l}\text { (1)代表簡易 } \\
\text { 予測図による } \\
\text { 変形量算定 }\end{array}$ & $\begin{array}{l}\text { (2)簡易予測図 } \\
\text { による変形量 } \\
\text { 算定 } \\
\end{array}$ & $\begin{array}{l}\text { (3)ニューマーク } \\
\text { 法による変形 } \\
\text { 量算定 }\end{array}$ & $\begin{array}{l}\text { (4)残留変形解析 } \\
\text { (FEM等)による } \\
\text { 変形量算定 }\end{array}$ \\
\hline $\begin{array}{l}\text { 手法の } \\
\text { 煩雑さ }\end{array}$ & 簡易 & & & 詳細 \\
\hline $\begin{array}{l}\text { 算定 } \\
\text { 変形量 }\end{array}$ & 大きめ & & & より㧛密 \\
\hline $\begin{array}{l}\text { 検討の } \\
\text { 手順 }\end{array}$ & 簡易法 & 件や現地調查結身 & を基により詳練な力 & 法で検討 \\
\hline
\end{tabular}

図-18＼cjkstart而震性評価手法と適用

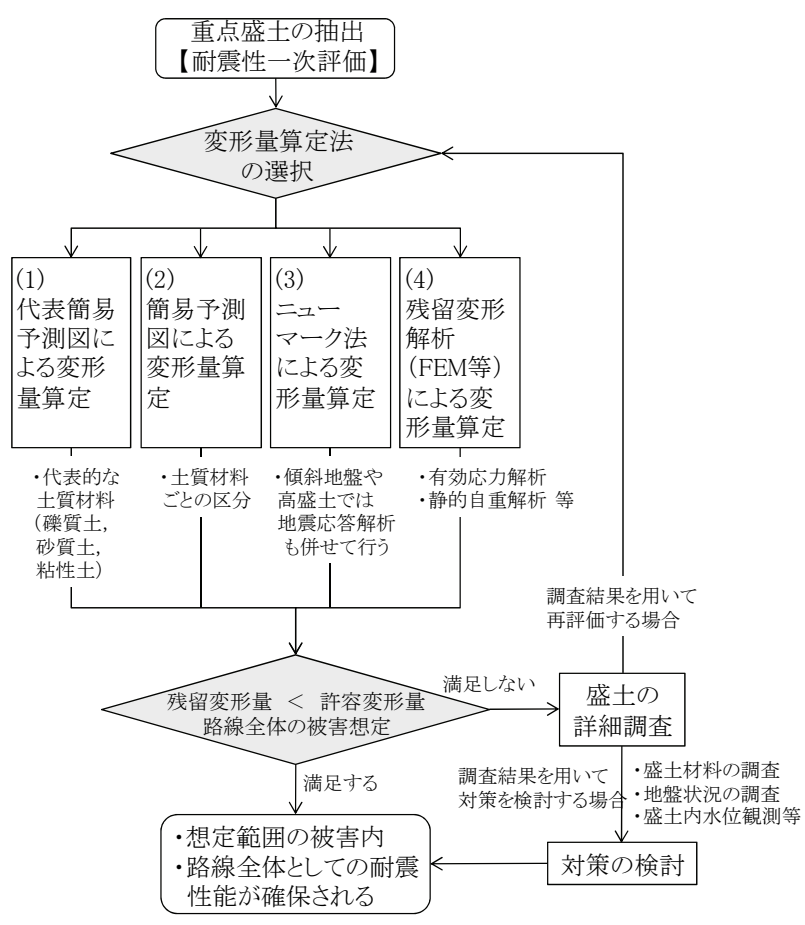

図-19而震性評価手法の適用の流れ

\section{7. 耐震性能照査法 (二次評価手法) の検討}

\section{（1） 耐震性能照査法の基本方針}

而震性能照査（而震性二次評価）は，一次評価で重点 盛土として抽出された盛土に対し，適切な手法により変 位・変形量 (残留変形量) を算定し，被災規模を想定し た上で，而震性の総合評価を行う。而震計算を実施する 上では，一次評価で抽出された重点盛土箇所に対し，す べてを詳細な解析により変形量を求めることは現実的で はない. したがって，得られている盛土の情報（盛土材 や地盤状況）や，万一崩壊した場合の周辺施設への影響 等, 盛土が変形した時の重要性に応じて, 適切な手法に より変形量を算定することが合理的であると考えられる. 図-18に評価手法と, 手法の詳細度, 変形量算定の㛜密 さのイメージを示す.ここでいう簡易手法とは, 図-20 のようにあらかじめ, 盛土材料, 盛土高さごとに二ュー

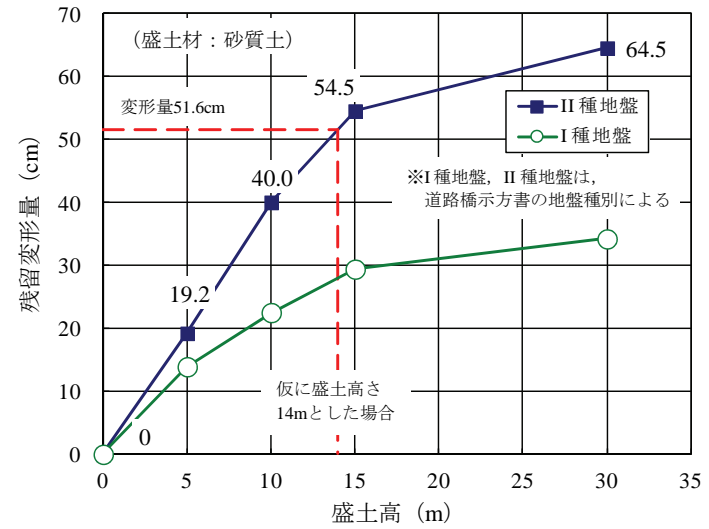

図-20 平坦地盤上盛土の盛土高に応じた残留変形量

マーク法 ${ }^{30}$ で変形量を計算したチャートを作成しておき, この算出条件に当てはまると考えられる場合は，チャー 卜（ここでは，「簡易予測図」という。）で変形量を算 出する手法である．簡易予測困による手法等の簡易法で 得られた変形量に応じて，より詳細に検討する必要があ れば，詳細法に移行していく，一次評価で抽出された重 点盛土であっても，二次評価で計算による変形量を算出 してもそれほど大きくない場合もある，したがって，照 査法の手順としては，図-19のようにまず簡易手法を活 用して変形量を算出し，大きな変形量であれば，二ュー マーク法 ${ }^{30}$ による変形量の算出や, 残留変形量解析に移 行していく.

\section{（2）簡易予測図による残留変形量の算出}

簡易的に盛土の地震時の残留変形量を算出する方法は, 図-20に示簡易予測困により算出する。この簡易予測 図は，盛土内水位のない高さ30m以下の平坦地盤上の法 面勾配が1:1.8である盛土を対象に，設計基準 ${ }^{18)}$ に示され る砂質土の土質定数の場合に，レベル2地震動を入力地

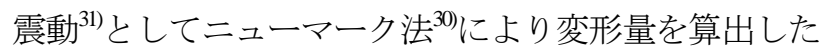
結果である.なお, レベル2の地震動としたのは, 一次 評価手法を構築した中越地震の対象範囲が，図-6に示し たようにレベル2と見なせるような大きな計測震度であ つたことや，第2章に示したように，変形量を許容する 盛土の要求性能としてはレベル2地震動の場合であるこ とによる.

\section{（3）簡易予測図による残留変形量の割増し}

簡易予測困は平坦地盤上の水位のない盛土を対象とし ているため，地盤傾斜がある場合や盛土内水位がある場 合で，簡易予測図を用いて評価を行う場合は，それらの 影響を考慮した変形量の算出が必要である.したがって， 地盤傾斜や盛土内水位がある場合は，別途地震応答解析 や水位を考慮した解析を行い，その結果で簡易予測困の 変形量を割増しすることとした. 


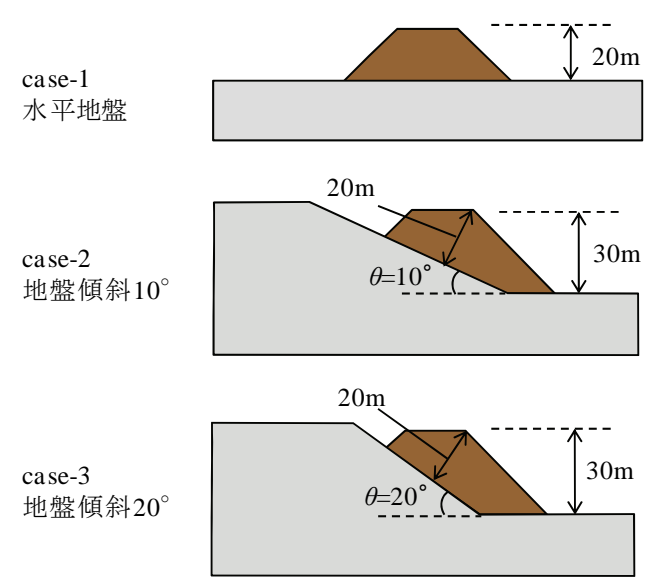

図-21＼cjkstart地盤傾斜の影響検討のモデル図

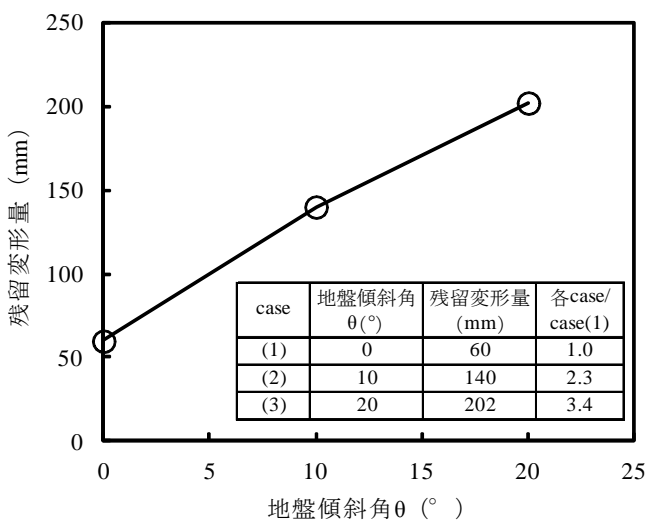

図-22 地盤傾斜角度と残留変形量

\section{a）地盤傾斜による補正}

傾斜地盤の場合，平坦地盤の盛土に比べて地震動が増 幅され，盛土の残留変形量も大きくなることが考えられ る.したがって，図-21 に示すモデル地盤で地盤傾斜の 影響を確認し，簡易予測図で得られる変形量の割増しを 検討した．傾斜地盤では盛土が谷地形や沢地部にあるた め高盛土になる場合が多い，そこで盛土高さは盛土小段 2 段以上を想定して平坦地盤上での高さ $20 \mathrm{~m}$ を基本とし た. また，同じ盛土高さで地盤傾斜を可変すると盛土厚 が薄くなることによる地震動増幅の影響が大きくなる. そのため, 本モデルでは地盤傾斜の影響のみをみるため, 盛土厚さは $20 \mathrm{~m}$, 盛土高さは $30 \mathrm{~m}$ に固定して地盤傾斜 を $10^{\circ} ， 20^{\circ}$ の 2 ケース設定した. なお，すべりの対 象とする円弧は，道路本線に影響がない盛土法面表層部 の小崩壊は対象とせずに，加速度の増幅の影響が大きく かつ本線車線部まで影響が及ぶと考えられる盛土上部を 対象とし, 地盤傾斜の相対的な変化確認が目的であるの で，円弧高は法肩から $15 \mathrm{~m}$ の高さで固定して検討した 残留変形量の算出は，高速道路の設計基準 ${ }^{30}$ にある ように，地震動の地表面波(ここでは能登有料道路の盛 土をモデルにしたので，能登半島地震の K-NET 富来の 観測波を用いた)を基盤に入力し，地盤を含めた盛土の 地震応答解析を行って，盛土すべり土塊の等価加速度波 形を求め, この加速度波形を用いてニューマーク法で残 留変形量を算出した.

解析に用いた地盤定数は能登有料道路で被災した縦38 盛土 ${ }^{32}$ をモデルにした．なお，この盛土は盛土内水 位が表層にあり大規模崩落した箇所である. 盛土材料を ロームとして湿潤単位体積重量 $14\left(\mathrm{kN} / \mathrm{m}^{3}\right)$, 粘着力 $c=12\left(\mathrm{kN} / \mathrm{m}^{2}\right)$, 内部摩擦角 $\varphi=23^{\circ}$ で設定した。 また，盛 土の変形特性や岡性は設計基準にしたがって設定した.

検討結果を図-22 に示寸. 平坦地盤の場合, 等価加速 度波形の最大值は $482\left(\mathrm{~cm} / \mathrm{s}^{2}\right)$ で残留変形量は $60 \mathrm{~mm}$ とな った. $10^{\circ}$ 傾斜地盤の場合は等価加速度の最大值は $535\left(\mathrm{~cm} / \mathrm{s}^{2}\right)$ で残留変形は $140 \mathrm{~mm}, 20^{\circ}$ 傾斜の場合は
581 $\left(\mathrm{cm} / \mathrm{s}^{2}\right)$ で $202 \mathrm{~mm}$ となった. $10^{\circ}$ 傾斜の場合の残留変 形は平坦地盤の 2.3 倍, $20^{\circ}$ 傾斜の場合は 3.4 倍となっ た. なお，同様のモデルで静的自重解析 ${ }^{15)}$ でも検討して いる. 静的自重解析は 2 次元液状化流動解析プログラム (ALID)を使用した. 解析に用いた物性は， $N$ 值=10 とし て $E=2800 N$ の関係からせん断岡性 $G=5200\left(\mathrm{kN} / \mathrm{m}^{2}\right)$ を求め, 縦-38 の盛土材料の繰り返し非排水三軸試験の結果から 液状化強度比 $R=0.43$, 地震時応答解析の結果から地震時 せん断応力比 $L=0.61$ を求め $F_{\mathrm{L}}=0.6$ とした. その結果に おいても平坦地盤と傾斜地盤の残留変形量の比率は, $10^{\circ}$ 傾斜地盤で 2.6 倍， $20^{\circ}$ 傾斜地盤で 3.3 倍となること を確認している.この結果の $10^{\circ} \sim 20^{\circ}$ の中間的な值 を用いて，本検討では傾斜地盤上の盛土は地盤傾斜の影 響に対する割増しとして，平坦地盤上の盛土において算 出した残留変形量を 3 倍することとした. なお，一次評 価手法における平坦地盤と傾斜地盤の区分は，傾斜 $5^{\circ}$ を境にしており, 対象盛土の抽出方法も平坦地盤と傾斜 地盤の 2 区分で行っている. 上記検討では $10^{\circ} \sim 20^{\circ}$ の結果で変形量を 3 倍としており, 傾斜 5 の区分では 傾斜角が $5 \sim 10^{\circ}$ 程度の場合, 変形量は大きくなるが, ここでは，変形量は安全側の評価になり，検討も簡便化 できるために地盤傾斜による補正の区分も傾斜 $5^{\circ}$ を境 に設定した.

\section{b) 盛土内水位による補正}

地盤傾斜と同様に，盛土内水位が有る場合の検討は能 登有料道路で被災した縦-38 盛土をモデルにした。図-23 にモデルを示す. 法尻部で $2.5 \mathrm{~m}$ と $5.0 \mathrm{~m}$ の 2 水位を設定 し，地盤からの地震応答解析を行った加速度波形を用い て各々の残留変形量を算出した。結果を図-24 に示す. 盛土水位がない場合残留変形量は $170 \mathrm{~mm}$, 水位 $2.5 \mathrm{~m}$ で は $304 \mathrm{~mm}$ ，水位 $5.0 \mathrm{~m}$ では $565 \mathrm{~mm}$ となり，水位 $5.0 \mathrm{~m}$ の 残留変形量は，水位なしの場合の 3.3 倍となった. この 結果の中間的な值を用いて，本検討では盛土内に水位が ある場合は，水位の影響に対する割増しとして，水位が ない盛土において算出した残留変形量を 3 倍することと 


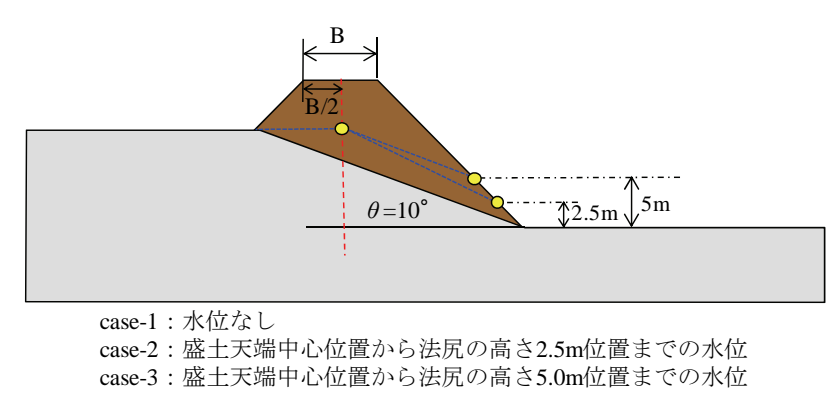

図-23盛土内水位の影響検討のモデル図

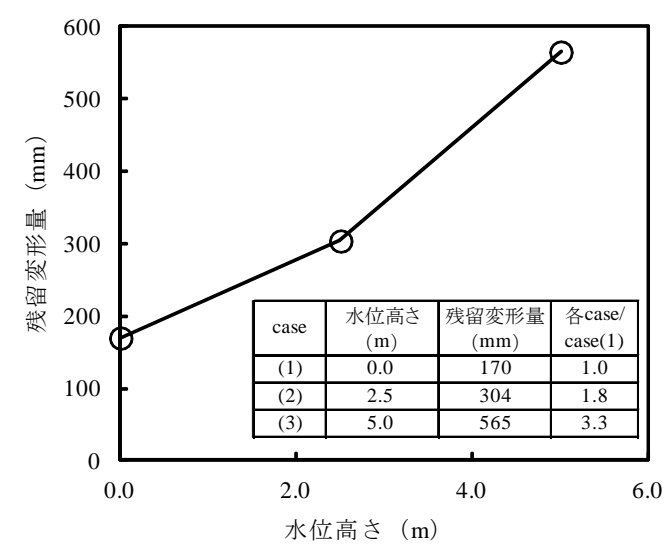

図-24 盛土内水位と残留変形量

表-5 地盤傾斜や水位がある場合の残留変形量割増し

\begin{tabular}{|c|c|c|c|}
\hline 項目 & 区分 & 割増し率 & 摘 要 \\
\hline \multirow{2}{*}{$\begin{array}{l}\text { 地盤の } \\
\text { 傾斜角 }\end{array}$} & $5^{\circ}$ 未満 & 1.0 & \multirow{4}{*}{$\begin{array}{l}\text { 左記の結果は, 特定の } \\
\text { 盛十条件で検討した結 } \\
\text { 果であるので, 盛土条 } \\
\text { 件が大きく異なる場合 } \\
\text { は割増し率を再考する } \\
\text { 必要がある. }\end{array}$} \\
\hline & $5^{\circ}$ 以上 & 3.0 & \\
\hline \multirow{2}{*}{$\begin{array}{c}\text { 盛土内 } \\
\text { 水位 }\end{array}$} & 無し & 1.0 & \\
\hline & 有り & 3.0 & \\
\hline
\end{tabular}

した. a),b)の結果より，簡易予測図の残留変形量の割増 しは，表-5のとおりとした。 なお，この表の割増し率 は図-21，図-23 の特定な盛土条件の結果であるので，条 件が大きく異なる場合は割増し率の再考が必要である.

\section{8. 許容残留変形量の設定方法}

\section{（1）許容残留変形量設定の基本方針}

許容残留変形量は, 高速道路の高盛土設計基準 ${ }^{18)}$ では, “高盛土の現地条件，路線全体を考慮した地震後におけ る復旧体制や車両通行の機能等を総合的に勘案して設定 する必要がある”としている，このように，修復性の高 い道路盛土は，本来は盛土に必要な交通機能と，それを 復旧できる体制等から許容変形量を設定すべきである.

一方，既存の許容変形量に関する考え方が示されてい る例を表-6 に示寸. 許容変形量の考え方は, どの例も
表-6 各基淮における許容残留変形量

\begin{tabular}{|c|c|c|}
\hline 基淮類 & $\begin{array}{l}\text { 許容残留 } \\
\text { 変形量 } \\
\end{array}$ & 内容 \\
\hline $\begin{array}{l}\text { 道路土工軟弱地盤 } \\
\text { 対策工指針 }{ }^{33)}\end{array}$ & $10 \sim 30 \mathrm{~cm}$ & $\begin{array}{l}\text { 舗装後 } 3 \text { 年間の許容残留沈下 } \\
\text { 量の目標值 } \\
\text { 橋梁・高架の接続盛土部 }\end{array}$ \\
\hline $\begin{array}{l}\text { 鉄道構造物等設計 } \\
\text { 標準・同解説而震 } \\
\text { 設計 }\end{array}$ & $\begin{array}{l}\text { 沈下量 } \\
20 \mathrm{~cm} \text { 以上 } \\
50 \mathrm{~cm} \text { 未満 }\end{array}$ & $\begin{array}{l}\text { レベル } 2 \text { 地震時の盛土被害と } \\
\text { 沈下量の目安で, 応急処理で } \\
\text { 復旧が可能な被害の場合（変 } \\
\text { 形レベル 2) }\end{array}$ \\
\hline $\begin{array}{l}\text { 土木構造物の震災 } \\
\text { 復旧技術マニュア } \\
\text { ル(案) }\end{array}$ & $\begin{array}{l}\text { 亀裂幅 } \\
\text { 30cm 以下又 } \\
\text { は段差量 } \\
\text { 50cm以下 }\end{array}$ & $\begin{array}{l}\text { 被災パターン II 型で, 盛土の } \\
\text { すべり崩壊又は亀裂, 段差の } \\
\text { 発生が道路車線まで及ぶもの }\end{array}$ \\
\hline
\end{tabular}

復旧シナリオを想定（具体的な対象路線に対して被災程 度・被災規模を想定）して設定されたものではなく, 復 旧体制や復旧時間に基づく許容変形量の考え方は示され ていない.

したがって，本検討では而震性能照査における許容変 形量は, 盛土の変形が周辺施設に及ぼす影響や，変形に 伴う復旧に要する時間等から決定する新たな視点で, 現 地状況や路線の特徵等から適切な許容变形量の設定法を 選択することとした。

具体な許容変形量の設定は以下の方法が考えられる.

\section{a) 盛土周辺の施設への影響を考慮した許容值}

盛土周辺の施設への影響が想定される場合には, 周辺 の施設へ影響を及ぼさないよう, 盛土が崩壊しない程度 の変形にとどめる必要がある．このため，b)のような復 旧シナリオを想定した上で残留変形量の許容值を想定す るのではなく一律の許容值とする．例えば，過去の震災 において崩壊はせず，段差被害に止まっている変形量と

して 50cm と設定すること等が考えられる.

\section{b) 目標復旧時間を達成可能な変形量の許容值}

災害時に復旧に要する目標時間を設定し, 路線全体の 被害 (変形量) が目標とする時間内に復旧できる変形量 を許容值とするやり方（復旧シナリオを策定し，被害の 程度が目標とする時間内に収まるかどうかで設定）。

\section{c) 過去の被災事例から想定する許容值}

新潟県中越地震等の過去の地震被災事例から, その時 に要した復旧時間と被害状況（変形量）により，復旧可 能な被害程度を想定し許容值とするもの. 新潟県中越地 震では, 地震発生から 19 時間で工事車両や緊急車両が 通行可能になっている ${ }^{29}$.

\section{d) 緊急車両の通行性から設定する許容值}

緊急車両が構造物との境界に発生した段差を, 物理的 に通行可能であるかどうかでその段差量を許容值とする 考え方である．橋台背面部に長さ $5 \mathrm{~m}$ の踏掛版がある場 合, 車両諸元から低床トレーラの場合の通行可能な段差 


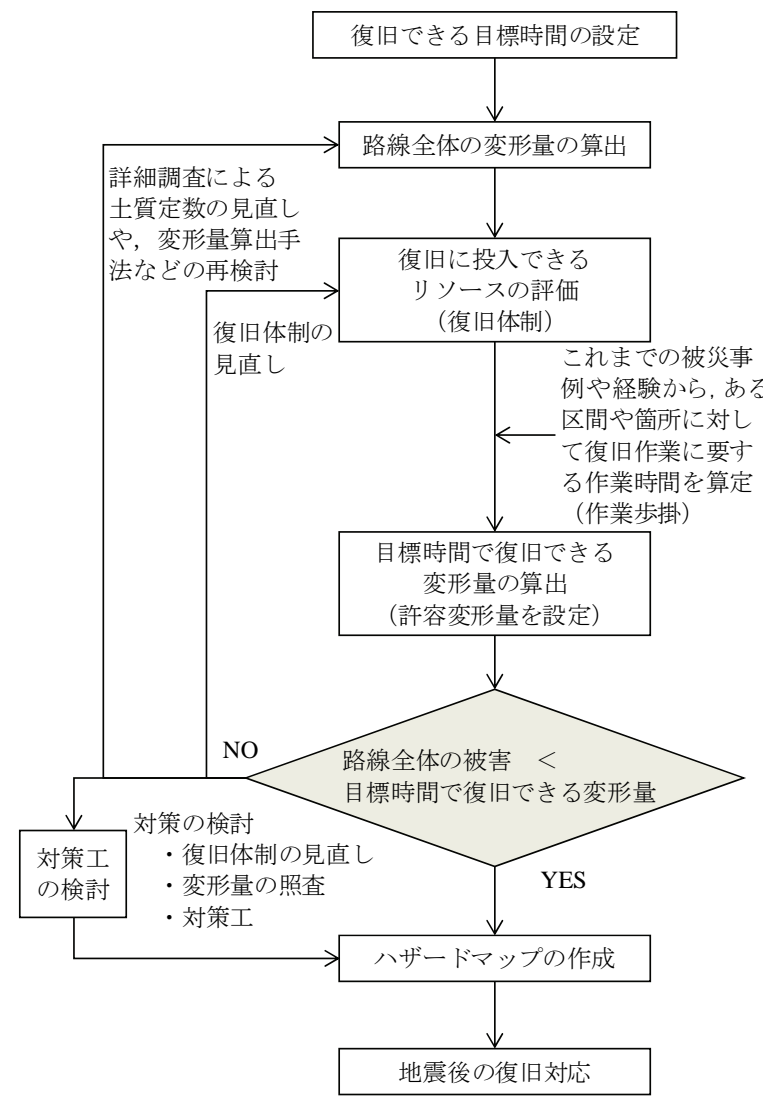

図-25復旧シナリオに基づく耐震性能照查法の流れ

量は約 $20 \mathrm{~cm}$ ，乗用車の場合約 $70 \mathrm{~cm}$ 程度となる ${ }^{15)}$.

\section{(2) 目標復旧時間を達成可能な変形量の許容値}

ここでは，8.(1) b)で示した目標復旧時間を達成可能な 復旧量から算定する許容変形量の設定方法について検討 する.

\section{a) 復旧シナリオに基づく許容残留変形量の設定手順}

復旧シナリオに基づく許容残留変形量の設定手順を図 -25 に示す. 以下の手順で検討する.

1) 許容残留変形量を仮定した上で，復旧総量を想定

耐震性二次評価において算定された残留変形量を 用い，許容残留変形量を仮定した上で，復旧に必要と なる総土量を算定する. このとき，仮定した許容残留 変形量を上回る範囲の盛土は, 震前対策が実施され, 計算值のような大きな変形が発生しないものと仮定す る.

2) 復旧方法等を仮定, リソースを評価した上で，復旧 速度の算定

緊急措置，緊急復旧方法を仮定した上で，復旧に 投入できるリソース（労働力，資材等）を評価し，復 旧速度（復旧土量あたりの必要復旧時間）を算定する。

3) 必要となる復旧時間を算定

復旧総量と復旧速度から, 必要となる復旧時間を 算定する.
表-7 中越地震における復旧作業体制と作業時間

\begin{tabular}{|c|c|c|c|c|c|c|c|c|}
\hline \multirow[b]{2}{*}{$\begin{array}{l}\text { 管理 } \\
\text { 区分 }\end{array}$} & \multirow[b]{2}{*}{$\begin{array}{l}\text { 作業 } \\
\text { 会社 }\end{array}$} & \multirow[b]{2}{*}{ 作業内容 } & \multirow[b]{2}{*}{$\begin{array}{c}\text { 参集 } \\
\text { 時間 } \\
(\mathrm{hr})\end{array}$} & \multicolumn{2}{|c|}{ 到着時間 (hr) } & \multicolumn{2}{|c|}{ 作業時間 (hr) } & \multirow[b]{2}{*}{$\begin{array}{c}\text { 作業 } \\
\text { 人員等 }\end{array}$} \\
\hline & & & & $\begin{array}{l}\text { 参集 } \\
\text { 完了 } \\
\text { 現場 } \\
\text { 到着 }\end{array}$ & $\begin{array}{l}\text { 地震 } \\
\text { 発生 } \\
\sim \text { 現場 } \\
\text { 到着 }\end{array}$ & $\begin{array}{l}\text { 現場 } \\
\text { 到着 } \\
\text { 作業 } \\
\text { 完了 }\end{array}$ & $\begin{array}{l}\text { 地震 } \\
\text { 発生 } \\
\text { 作業 } \\
\text { 完了 }\end{array}$ & \\
\hline $\begin{array}{c}\text { A } \\
\text { 事務所 } \\
\text { 管内 }\end{array}$ & A 社 & $\begin{array}{l}\text { •土のう作製 } \\
\text { •段差箇所に土 } \\
\text { のう, 砕石で段 } \\
\text { 差すり付け }\end{array}$ & 2 & 1 & 3 & 16 & 19 & $\begin{array}{l}\text { 職員: 7 12名 } \\
\text { 作業員: } 32 \text { 名 } \\
\text { 4t卜ラック: 台 } \\
\text { 2tトラック: 9台 }\end{array}$ \\
\hline $\begin{array}{c}\text { B } \\
\text { 事務所 } \\
\text { 管内 }\end{array}$ & B社 & $\begin{array}{l}\cdot \text { ·土のう作製 } \\
\text { •段差箇所に土 } \\
\text { のう, 砕石で段 } \\
\text { 差すり付け }\end{array}$ & 9.5 & 3 & 12.5 & 6.5 & 19 & $\begin{array}{c}\text { 職員4名 } \\
\text { 作業員15名 }\end{array}$ \\
\hline
\end{tabular}

表-8 中越地震における応急復旧時間

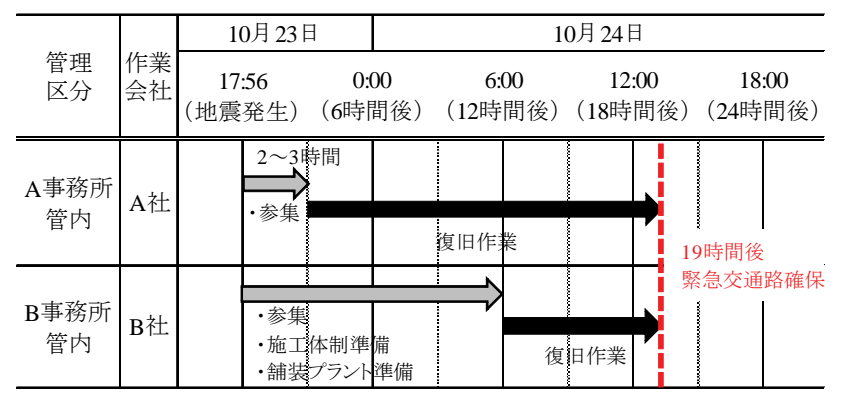

4) 目標とする復旧時間の範囲内であることを確認

算定された必要復旧時間が，目標とする復旧時間 の範囲内であることを確認し, 許容残留変形量を決定 する，なお，目標とする範囲内を超えている場合，許 容残留変形量を再仮定する，もしくは，リソースの再 評価を行った上で，許容残留変形量を決定する.

\section{b) 目標復旧時間の設定}

事業継続計画 (BCP: Business Continuity Plan) の考え方 は，災害時に重要業務が中断しない，万一中断しても目 標復旧時間内に再開させ，リスクを最低限に抑えるため に平常時に戦略的に準備する計画である.この BCP は 高速道路事業等の公共事業者にも必要とされている ${ }^{35)}$. 高速道路盛土における地震災害に置き換えると, 盛土が 万一損傷しても, 目標とする復旧時間内に，ある程度交 通を確保することにある. したがって, 検討の前段で, 事業者が社会的なコンセンサスを得られる範囲で目標と する復旧時間を設定する必要があり，高速道路盛士では， 災害後, 緊急車両に限っては 1 日以内に通行可能な程度 の損傷に止めるといら考えで行っている ${ }^{14)}$.

\section{c) 復旧作業に要する作業時間の算出}

新潟県中越地震での復旧事例によると，全体の被災量 に対して復旧作業班が作業をして，緊急車両が通行可能 となる緊急交通路の確保は，19 時間以内に完了してい る. ここでの検討は緊急車両が通行可能となる地震時の 復旧目標時間を 1 日以内とする.

中越地震における関越道全体の被災状況を図-26に示 


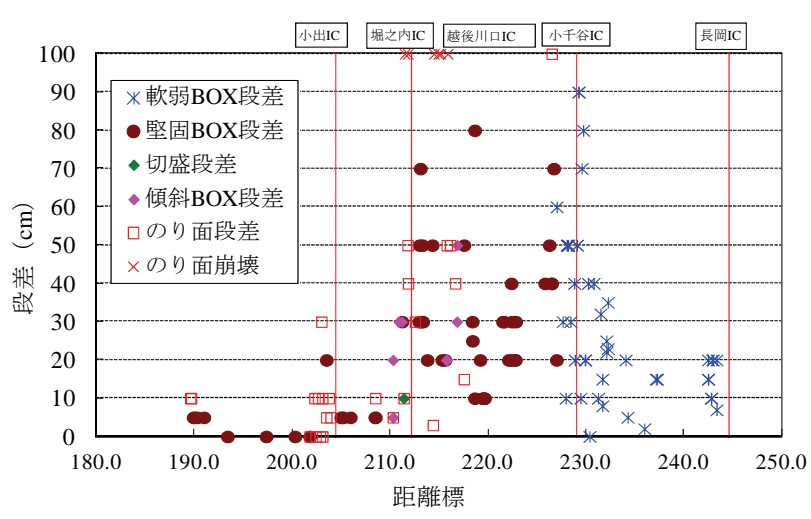

図-26 中越地震における関越道の変形量と位置

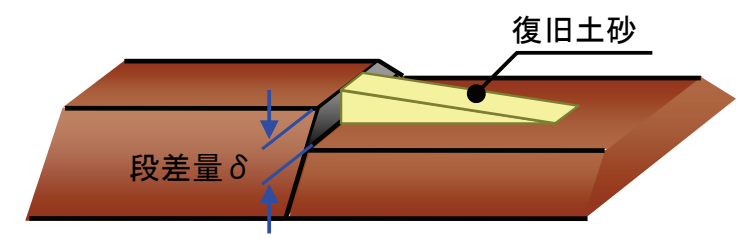

【復旧土砂寸法】

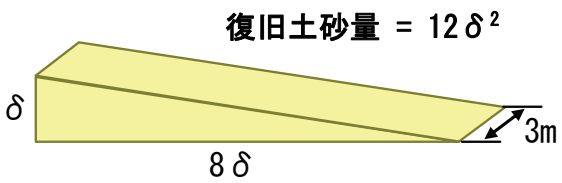

図-27 段差被害の応急復旧形状

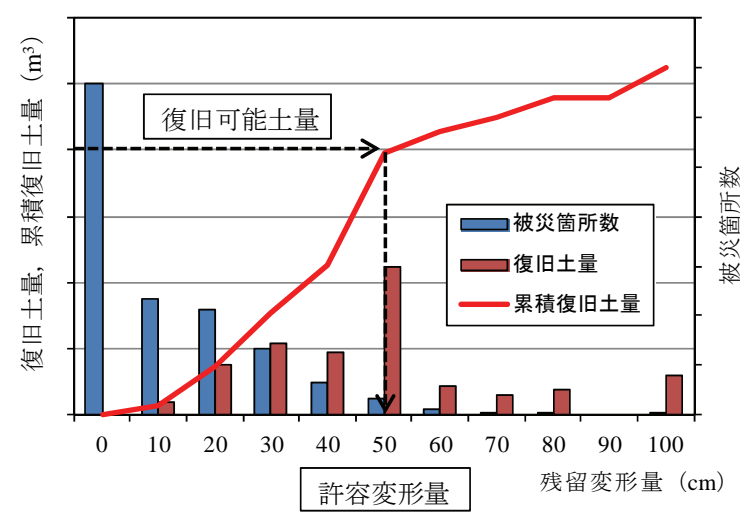

図-28＼cjkstart累積復旧土量と許容残留変形量の概念図

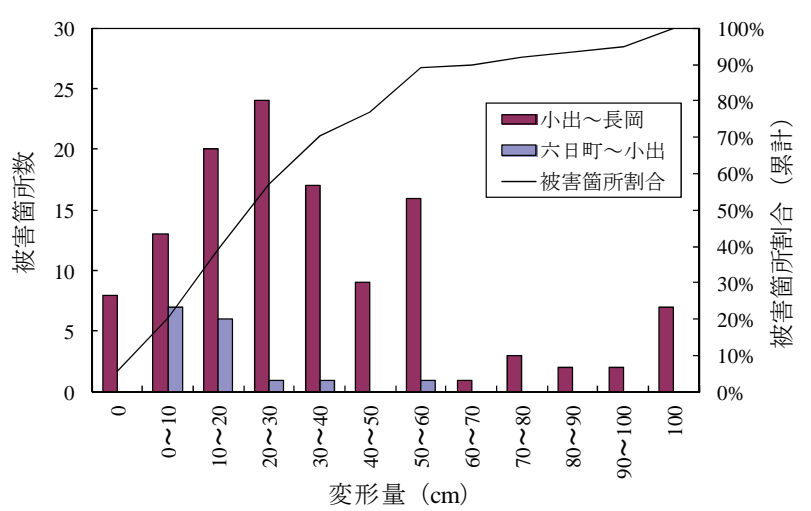

図-29 中越地震における変形量とその割合

表-9 主な地震における盛土被害と応急復旧時間

\begin{tabular}{|c|c|c|c|c|c|c|}
\hline \multirow[b]{2}{*}{$\begin{array}{l}\text { 発災 } \\
\text { 年 }\end{array}$} & \multirow[b]{2}{*}{ 地震 } & \multirow[b]{2}{*}{ 路線 } & \multirow[b]{2}{*}{ IC/JCT 区間 } & \multirow[b]{2}{*}{ 被害概要 } & \multicolumn{2}{|c|}{ 復旧に要した時間 } \\
\hline & & & & & $\begin{array}{l}\text { 緊急車両通 } \\
\text { 行可能まで }\end{array}$ & $\begin{array}{l}\text { 一般車両通 } \\
\text { 行可能まで }\end{array}$ \\
\hline 1978 & $\begin{array}{l}\text { 宮城県 } \\
\text { 沖地震 }\end{array}$ & 東北道 & $\begin{array}{c}\text { 泉〜大和 } \\
\text { 福島飯坂〜国見 }\end{array}$ & $\begin{array}{l}\text { 盛土の沈下 (30cm以下程度) } \\
\text { 橋台との路面段差 (30cm程度) }\end{array}$ & $\begin{array}{l}- \\
- \\
\end{array}$ & $\begin{array}{l}\text { 約 } 62 \text { 時間 } \\
\text { 約 } 47 \text { 時間 }\end{array}$ \\
\hline 2004 & $\begin{array}{l}\text { 新潟県 } \\
\text { 中越 } \\
\text { 地震 }\end{array}$ & $\begin{array}{l}\text { 関越道 } \\
\text { 北陸道 } \\
\end{array}$ & $\begin{array}{l}\text { 六日町〜小出 } \\
\text { 小出〜長岡 } \\
\text { 柏崎〜長岡 } \mathrm{J}\end{array}$ & $\begin{array}{l}\text { 最大路面段差 } 50 \mathrm{~cm} \\
\text { 盛土部分崩壊以上 } 5 \text { 箇所, } \\
\text { 最大路面段差 } 100 \mathrm{~cm} \text { (平均 } 30 \mathrm{~cm} \text { ，概ね } 250 \mathrm{~cm} \text { 以下程度) } \\
\text { 最大路面段差 } 60 \mathrm{~cm} \text { （平均 } 10 \mathrm{~cm} \text { ，概ね } 220 \mathrm{~cm} \text { 以下） }\end{array}$ & $\begin{array}{l}\text { 約 19時間 } \\
\text { 約 19時間 } \\
\text { 約 19時間 }\end{array}$ & $\begin{array}{l}\text { 約 } 138 \text { 時間 } \\
\text { 約 } 13 \text { 日 } \\
\text { 約 } 76 \text { 時間 }\end{array}$ \\
\hline 2007 & $\begin{array}{l}\text { 新潟県 } \\
\text { 中越沖 } \\
\text { 地震 }\end{array}$ & 北陸道 & $\begin{array}{c}\text { 長岡 J〜柏崎 } \\
\text { 柏崎〜米山（上り） } \\
\text { 柏崎〜米山（下り） } \\
\text { 米山〜柿崎 }\end{array}$ & 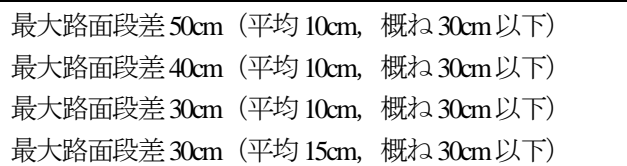 & $\begin{array}{l}\text { 4時間 } \\
4 \text { 時間 } \\
4 \text { 時間 } \\
4 \text { 時間 }\end{array}$ & $\begin{array}{l}26 \text { 時間 } \\
26 \text { 時間 } \\
26 \text { 時間 } \\
26 \text { 時間 }\end{array}$ \\
\hline
\end{tabular}

す.この被災量に対して，実際の応急復旧工事における 作業体制，現場到着時間，作業完了時間等の作業状況を 表-7，表-8 に示す．表中に示すように，いずれの事務 所管内においても応急復旧が終了するまでに，参集時間 を含めて 19 時間以内であった. 大規模な地震災害時に は，復旧作業に取り掛かるまでの，参集連絡時間，現場 事務所までの参集時間，現場事務所から被災現場までの 移動時間がかなりの時間必要で，実際の復旧作業時間は それほど長くない，表-8の B 社のように，作業時間は 半日程度ほどで集中的に行われる場合もある。

\section{d) 復旧可能土量の算定}

応急復旧段階では，図-27 のように幅 $3 \mathrm{~m}$, 勾配 1:8 程 度の復旧形状で段差部の応急的なすりつけがされている. このような復旧形状を仮定して，図-26 の実測段差量を 基に全体の復旧土量を算定すると，被災 96 箇所で約 $173 \mathrm{~m}^{3}$ となった. 全体土量加ら作業 1 班当りの復旧可能 土量を算出すると，以下のように算定できる.

1班当たりの復旧速度 $=$

19 時間 / (復旧総土量 $173 \mathrm{~m}^{3} / 3$ 班) $=$ 約 20 分 $/ \mathrm{m}^{3}$ 24 時間当たりの復旧可能土量 $=$

24 時間 $/ 20$ 分 $/ \mathrm{m}^{3}=$ 約 $70 \mathrm{~m}^{3}$ 
となる. 1 作業班が参集時間も含めて 24 時間に作業で きる復旧土量の $70 \mathrm{~m}^{3}$ を復旧作業量（作業歩掛）とした.

\section{e) 許容残留変形量の算出}

復旧に要する期間で算出する許容残留変形量は, 耐震 性二次評価で算出した路線全体の残留変形量と復旧可能 作業量の関係で算出する. 図-28 にその概念を示す．横 軸には残留変形量を小さい順に並へ，縦軸は箇所数とそ の箇所で算出される土量を累積した累積復旧土量とする。 d)で算定した復旧可能土量を縦軸にとり，それに対応す る残留変形量が許容残留変形量となる.

この結果，累積復旧土量が復旧可能土量を下回る場合 は，特に対策を講じなくても 24 時間以内に応急復旧可 能な程度の被災であると判断できる，一方，累積復旧土 量が復旧可能土量を上回る場合，許容変形量以上の箇所 に，震前対策を実施すれば復旧の目標時間を達成するこ とができる.

\section{（3）過去の被災事例から想定する許容値}

新潟県中越地震等の過去の地震被苂事例から，その時 に要した復旧時間と被害状況（変形量）により，復旧可 能な被害程度を想定し許容值とするものである．表-9 に盛土被害の大きかった地震災害と緊急車両が通行可能 になるまでの時間をまとめた．新潟県中越地震では地震
発生から 19 時間で, 中越沖地震では発生から 4 時間で 工事車両や緊急車両が通行可能になっている．図-29 は 新潟県中越地震での被害状況の分布と, 段差被害等の程 度と箇所数をまとめたものである。これによれば，被害 全体の 9 割近くが変形量 $70 \mathrm{~cm}$ 程度である. この結果か らは，過去の地震と同程度の被災状況や，路線状況を想 定した場合, 緊急車両が通行可能となる地震時の復旧目 標時間を仮に 1 日以内とすると, 変形量 $70 \mathrm{~cm}$ 程度であ れば，目標を達成可能と想定できる.

\section{9. モデル路線における適用}

\section{(1) 対象路線}

これまでに検討した盛土の耐震性評価手法を用いて, 実際の路線をモデルにして適用した．対象路線は10IC間， 延長約71kmである.

\section{（2）重点盛土の抽出（一次評価手法）}

盛土の基本条件による抽出(評価-II)による結果を図-30, 図-31に示す。これは平坦部の代表IC間と山岳部の代表 IC間の結果である. 図の青塗りは平坦地盤上の箇所，青 斜線は傾斜地盤上の箇所である.ここでは抽出の評価点

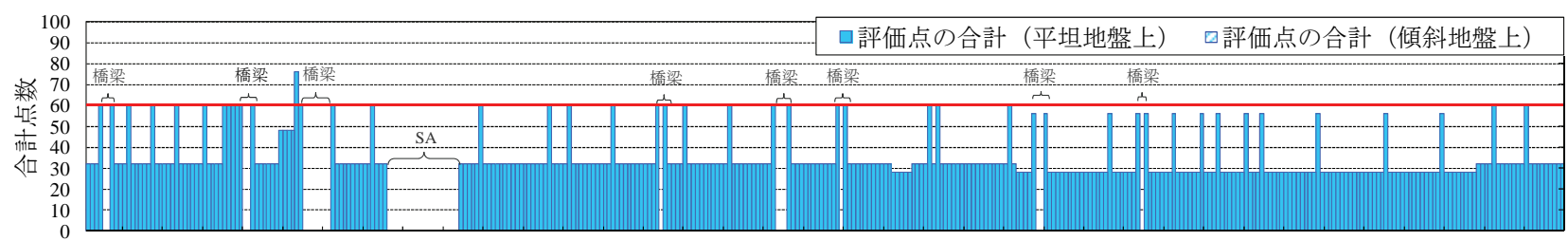

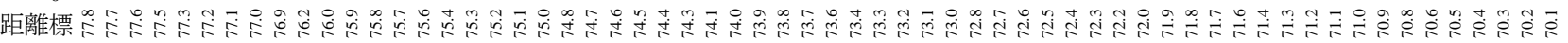

図-30 評価-Iによよる平坦地盤上の重点盛土抽出結果（平坦部の代表IC間）

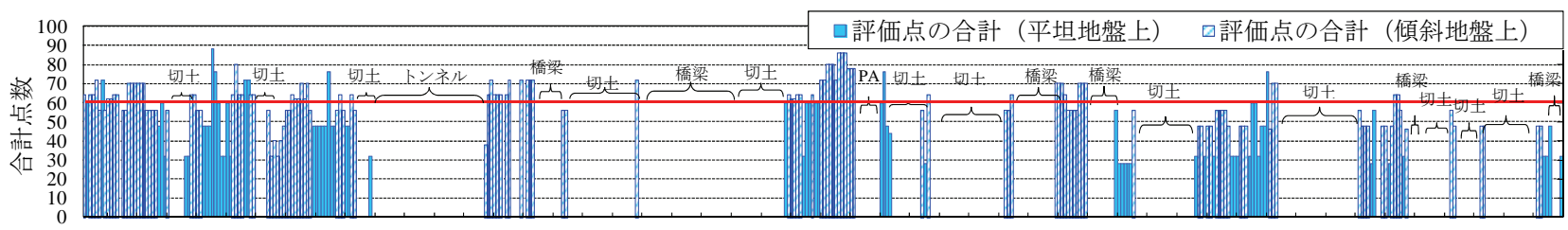

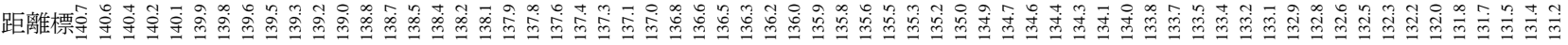

図-31 評価-IIによる傾斜地盤上の重点盛土抽出結果（山岳部の代表IC間）

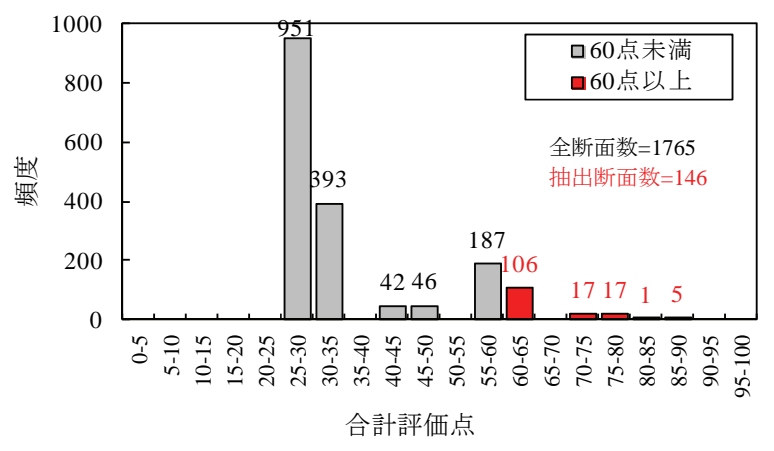

図-32＼cjkstart評価-IIよよる平坦地盤上の評価点分布

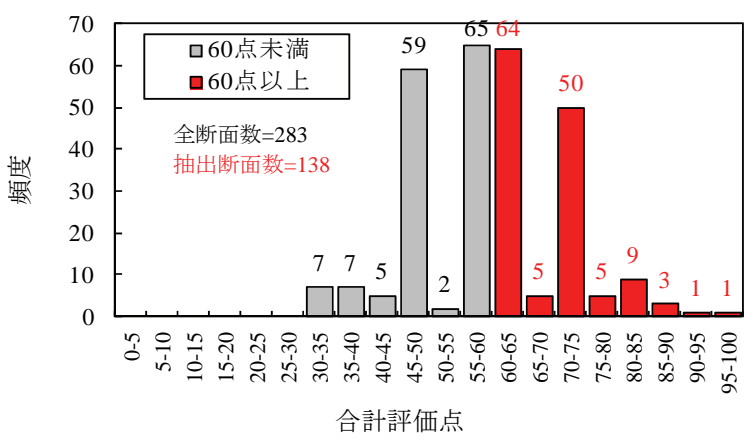

図-33＼cjkstart評価-Iによる傾斜地盤上の評価点分布 
の閾値は60点以上とした. 抽出した箇所の評価点の分布 を図-32，図-33に示す．図-32は平坦地盤上の盛土の抽出 結果で，対象断面数1765断面に対して，閾值を上回る抽 出箇所は146断面(8\%) となった。 また, 図-33は傾斜地盤 上の盛土抽出結果で, 対象断面数283断面に対して, 抽 出箇所は138断面(49\%)となった．全体では対象2048断面 に対して，抽出されたのが284断面で全体の14\%となっ た。傾斜地盤上の抽出割合が多いが，全体としては14\% となり，実務で対策を検討する上では現実的な抽出割合 と考えられる.

\section{(3) 残留変形量の算出 (二次評価手法)}

図-34，図-35 に図-20 に例を示した簡易予測図による
残留変形量の算出結果を示寸，なお，変形量は図-3に 示した一次評価手法のうち, どの評価で抽出されたか色 分けしている. 図-34 は平坦部の代表 IC 間の結果である. ほとんどの箇所が 20〜30cm 程度の残留変形量となった。 図-35 は山岳部の代表 IC間の結果である. 残留変形量は 20 140cm 程度で, 箇所によっては大きな変形量となっ ている. $100 \mathrm{~cm}$ を超える変形量が予測される箇所は, 傾 斜地盤の盛土である箇所がほとんどである．また，本検 討では盛土横断 $20 \mathrm{~m}$ ピッチごとに変形量を算出してい るが，図をみると変形量が大きい箇所が連続している. ほとんどの連続している断面は一つの盛土であるため, 一つの盛土箇所とみた場合, 変形量の大きい盛土箇所は それほど多くはない。

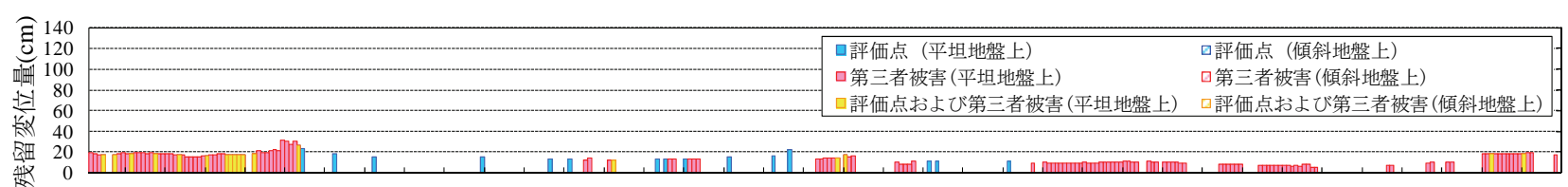

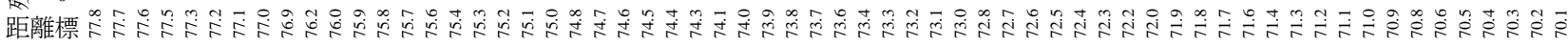

図-34 簡易予測図による残留変形量の算出結果（平坦部の代表IC間）

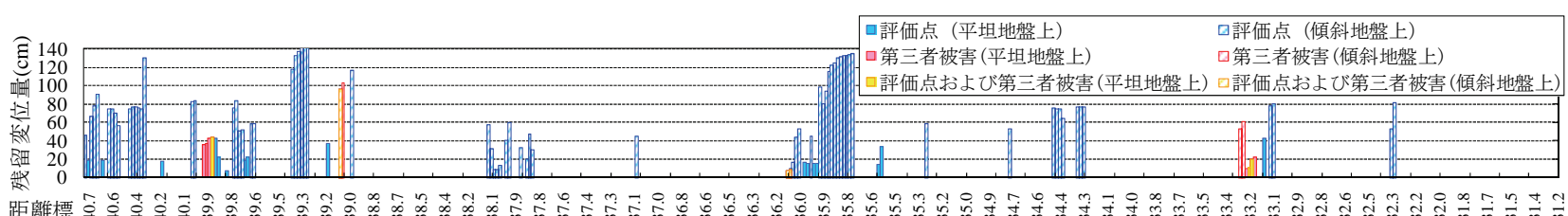

図-35 簡易予測図による残留変形量の算出結果（山岳部の代表IC間）

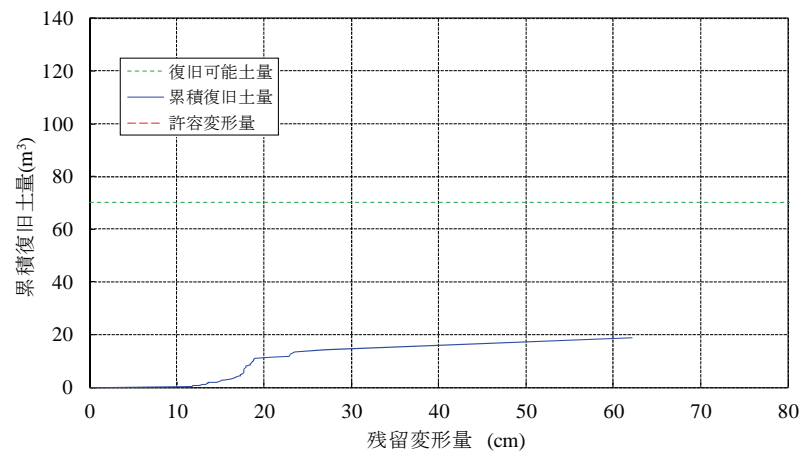

図-36 許容残留変形量の設定（平坦部の代表IC間）

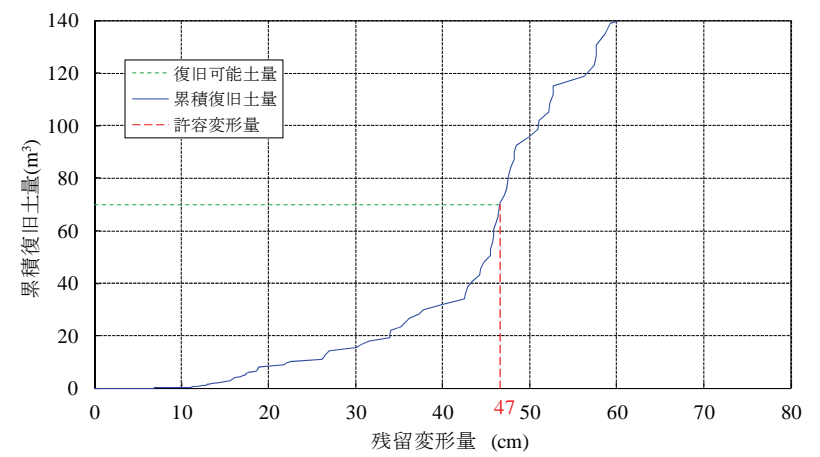

図-37 許容残留変形量の設定（山岳部の代表IC間）

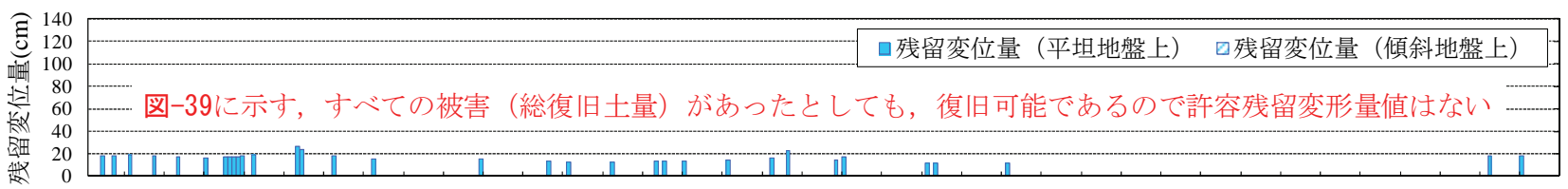

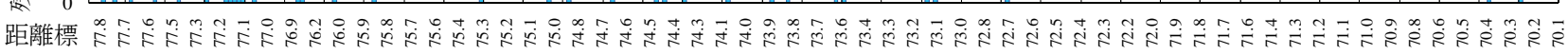

図-38 残留変形量と許容残留変形量 (平坦部の代表IC間)

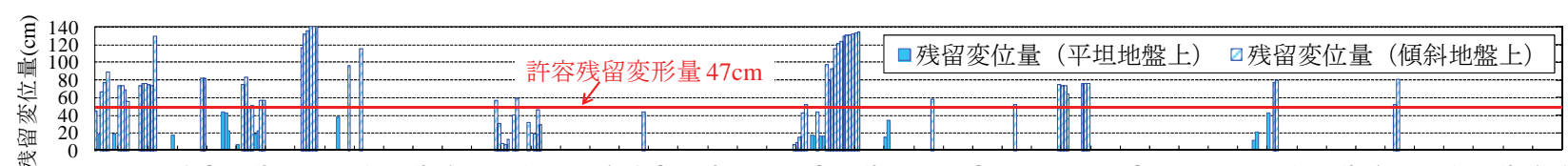

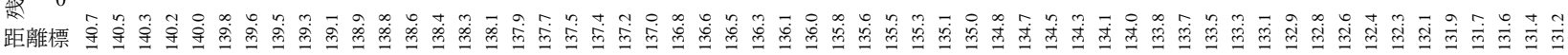

図-39 残留変形量と許容残留変形量（山岳部の代表IC間） 
図-36，図-37は残留変形量から復旧土量を算出し，累 積復旧土量対して, 復旧可能土量を $70 \mathrm{~m}^{3}$ として許容残留 変形量を設定した結果である. 図-36の平坦部の区間で は, 累積復旧土量が復旧可能土量を下回っているので, すべての被害に対して復旧可能である.この場合, 図38に示寸ように，このIC区間の各盛土箇所の耐震性能は 確保されており，特に対策を行う必要はないと判断でき る. 図-37の山岳部の区間では, 累積復旧土量による許 容残留変形量は47cmとなった。この場合, 図-39に示寸 ように, この区間の幾つかの盛土で許容残留変形量を超 える箇所がある，路線の全断面2048断面のうち，(2)で抽 出された重点盛土は284断面(全断面のうち14\%), さらに 而震性二次評価で，許容残留変形量を上回る盛土は118 断面(全断面のうち6\%)となった。許容残留変形量を上回 る場合は，これら箇所に何らかの対策が必要であると判 断できる.なお，今回の検討では図-37の山岳地の区間 の復旧作業班を1班として, 許容残留変形量を $47 \mathrm{~cm}$ と算 出したが，復旧体制を強化し，仮に2班体制で復旧作業 を行うとすれば，復旧作業土量が2倍になり許容残留変 形量は60cmとなる．このように復旧体制を強化するこ とによって, 許容残留変形量を上回る箇所を少なくする ことができ，体制強化も而震性向上の対策として評価す ることができた.

\section{（4）変形量を満足しない場合の対策の考え方}

而扵震性能照査の結果, 想定する復旧の目標時間や変形 量を満足しない場合, 図-40に示すように, 変形量算出 の見直しや，復旧体制の見直し，対策工の検討等の対応 を検討する．対応の検討にあたっては，現地条件や路線 の特徵を踏まえ, 合理的な対策を選択寸る必要がある. 以下，対策の考え方を示寸.

\section{a) 土質定数の見直し，変形量算出手法の見直し}

建設時の土質調查結果や，土質試験結果，工事施工記 録から，変形量算出に用いる土質強度定数や，土質構成， 原地盤の状況等の再精査を行い，土質条件等の設計条件 の精度を向上させる. また, 必要に応じて, 現場盛土の 詳細調査（ボーリングでの土質構成の確認, 土質試験で の盛土材料の強度定数の確認, 盛土内水位の確認等）を 行い, 設計条件の見直しを行う.

簡易予測図等を用いて, 変形量を算出している場合, 土質情報等が十分でないという前提から，比較的安全側 の算定量となっている．したがって，土質情報等を明確 にした上で，変形量算出手法についても，簡易的な手法 を用いている場合，より詳細な手法を用いて変形量を精 查する.

\section{b) 復旧体制の見直し}

変形に伴う復旧に要する期間等により許容值を設定し た場合，目標とする復旧時間を満足できない場合におい

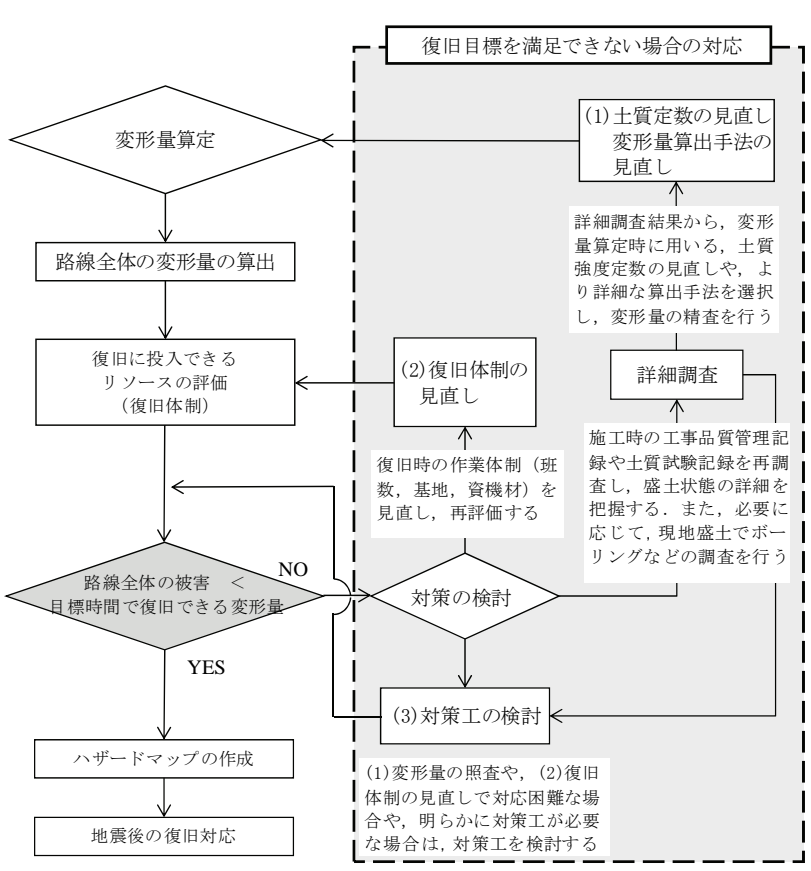

図-40復旧目標を満足できない場合の流れ

て，復旧体制の見直しで対応する考え方である．復旧作 業における作業量を復旧方法や作業機械，作業体制等を 見直して，単位時間内に復旧できる作業量が多くなるよ う体制強化する方法（作業効率を高める方法）と，体制 人員や班体制を多くし全体の作業量を多くなるような方 法（作業量を高める方法）が考えられる.

\section{c) 対策工の検討}

上記のa)，b)で対応できない場合や，盛土から著しい 湧水の発生や, 盛土内水位が高い場合, 安定性に懸念が 生じる変状がみられる場合は，対策工の検討を行う，対 策工の選定にあたっては, 盛土状態を適切に評価するこ とが重要であるので, 必要に応じて, 詳細点検, 詳細調 査をもとに検討することが必要である.

\section{0. 結論}

既設盛土の耐震性評価は，その対象が膨大であるため 比較的簡易な評価手法が必要であった. 検討では評価手 順として，まず検討対象となる盛土の抽出方法である耐 震性一次評価手法を行い，その次に残留変形量を算定す る耐震性二次評価手法を行う評価手順を示した. 本論文 での結論は以下のとおりである.

1) 一次評価手法は, 対象盛士の選定は評価者でばらつ きのでないように, 盛土の基本情報を基に点数化 して評価することを試みた。一般的に入手可能な 平面・横断図や地形・地質図の図面類により, 盛 土の基本情報をデータベース化し，その盛土条件 
と中越地震における盛土被災実態から評価する項 目を分析した，評価する項目は，盛土高さ，地形 分類, 表層地質分類, 地盤傾斜角, 構造物の有無 を設定し，評価する項目ごとの点数の重みは，可 能な限り定量的なものから設定寸るため, 数量化 理論によって重み分析を行った。その結果，被災 状況と地盤傾斜角の関係から，平坦地盤上の盛土 と，傾斜地盤上の盛土の評価項目を分けることと した． 評価点の設定は，評価項目の合計が 100 点と なるように設定した，その手法を中越地震の被災 区間に適用すると，閾值を 60 点とすると被災箇所 91 か所のうち，84 箇所を抽出できることが確認で きた.

2) 二次評価手法における残留変形量の算出では，あら かじめ残留変形解析であるニューマーク法を用い て, 盛土材料ごとに盛土高さと残留変形量の関係 をチャート化した簡易予測図を作成した。この図 を作成すれば対象箇所個々に詳細な計算をする必 要がなく, 誰でも簡便に変形量が算出できること を示した．なお，本論文で示した変形量はある特 定の盛土構造，材料などの条件で算出したもので あるので，す心゙ての条件を網羅したものではない したがって，盛土条件が異なる場合は，条件にあ った簡易予測図を作成すればよい.

3）災害時における緊急交通路の確保は，高速道路事業 者にとって, 最も重要な社会的な責務である. 緊 急交通路を確保する上では, 時間的な概念が必要 で，復旧目標時間という形で具現化されている. この復旧目標時間はNEXCOにおいても1日以内とし ており，災害マネジメント，或いは災害発生時の 災害復旧のプロジェクトマネジメントでは，共通 の目標となる復旧方針の柱である. 今回, 盛土の 耐震性を評価する上で，復旧目標時間を考慮した 復旧シナリオに基づく許容残留変形量の考え方を まとめた。具体には，中越地震における応急復旧 作業を事例に，段差被害の復旧形状を基に作業1班 が24時間で可能な復旧可能土量として70m³算出し, 耐震性二次評価で算出される路線各箇所の残留変 形量の復旧土量を合計して残留変形量と累積復旧 土量から許容残留変形量を算出する方法とした. なお，作業1班の復旧可能土量は対象とする路線に おける復旧体制（作業基地の位置，班体制，作業 機械等）によって異なるので，路線ごとに設定す るのが望ましい，この方法によって，従来の画一 的な許容変形量の設定ではなく, 現場の復旧体制 から設定する路線あるいはIC間ごとの許容変形量, すなわち盛土の性能を設定することが可能となっ た．これは，高速道路における災害時の事業継続
計画の根幹となるものである．また，この検討に よって震前対策において, 復旧に関わる作業員の 確保, 現場基地の位置, 復旧に必要な備蓄資材等 の適切な準備が可能となった。さらに，また路線 の重要度や走行車線数等加味する場合の, より現 実的な盛土耐震性評価の基礎検討となった.

4) 検討した而震性評価手法を用いて，実際の供用路線 をモデル路線とした検証を行った。その結果, 重 点盛土を抽出する耐震性一次評価では, 路線の全 断面2048断面のうち284断面(全断面のうち14\%)が抽 出され, 耐震性二次評価では, 許容残留変形量を 上回る盛土は118断面(全断面のうち6\%)となった. 許容残留変形量は, 山岳地のIC区間の作業班を1班 とすると $47 \mathrm{~cm}$ となった．仮に復旧体制を2班に強化 した場合, 許容残留変形量を上回る箇所を少なく することができ，体制強化も而震性向上の対策と して評価することができた.

本論文で構築した盛土耐震性評価手法によって, 効率 的に耐震対策の必要箇所を抽出することが可能になり， かつ合理的な対策工の優先度をつけられた.このことは 一連のシナリオに基づく作業を行うことによって，実務 的な盛土耐震対策を行うことを示したものである.

\section{参考文献}

1) 東日本高速道路(株), 中日本高速道路(株), 西日本高 速道路(株) : 設計要領第一集 土工編, 2010.

2) 水嶋忠雄, 牧浦信一: JH - 高速自動車道等の被災状 況之応急復旧等, 道路, 652 号(平成 7 年 6 月号), pp.27-35,1995.

3) 地盤工学会: 2004 年新潟県中越地震災害調查報告書, 2007.

4) 地盤工学会：2007 年新潟県中越沖地震災害調査報告 書, 2009.

5）土木学会, 地盤工学会 : 2007 年能登半島地震被害調 查報告書, 2007.

6) 高木宗男, 横田聖哉, 菅浩一, 安田進, 太田秀樹 : 東名牧之原地区における盛土のり面災害の実態, 第 55 回地盤工学シンポジウム平成 22 年度論文集, pp.193-196, 2010.

7) 安部哲生, 横田聖哉, 金田和男, 長尾和之: 東北地 方太平洋沖地震における高速道路の被害及び復旧状 況について, 地盤工学ジャーナル, Vol.7, No.1, pp.117-125, 2012.

8) 土木学会：土木構造物の耐震設計法等に関する第三 次提言, 2000.

9) 鉄道総合技術研究所 : 鉄道構造物等設計標準 - 同解 説 而震設計, 1999.

10）港湾空港技術研究所 : 港湾構造物の耐震性能照查型 設計体系について, 港湾空港技術研究所資料 1018, 2002.

11）国土交通省河川局治水課：河川構造物の耐震性能照 查指針（案），2007.

12）国土交通省河川局：大規模地震に対するダム耐震性 
能照査指針(案) ・同解説， 2005.

13) 国土交通省高速道路のあり方検討有識者委員会 : 東 日本大震災を踏まえた緊急提言，2011.

14）中日本高速道路(株)：CSR 報告書 2011， 2011.

15) 高速道路調查会 : 平成 15 年度土構造物の而震設計に 関する検討報告書， 2004 .

16) 大窪克己，浜崎智洋，北村佳則，稲垣太浩，佐伯宗 大, 濱野雅裕, 龍岡文夫 : 高速道路盛土の大規模地 震時の耐震性検討（その 1）～盛土材のせん断強度の 検討 , 第 39 回地盤工学研究発表会講演集, pp.1759-1760, 2004.

17) 大窪克己，浜崎智洋，北村佳則，稲垣太浩，濱野雅 裕, 佐伯宗大, 龍岡文夫 : 高速道路盛土の大規模地 震時の耐震性検討（その 2）～変位量による耐震性能 評価法の検討〜，第 39 回地盤工学研究発表会講演集， pp.1761-1762, 2004.

18）東日本高速道路(株), 中日本高速道路(株), 西日本高 速道路(株)：設計要領第一集 土工編，pp.6-1-6-57, 2010.

19) 土谷基大, 横田聖哉, 高木宗男, 中村洋丈, 濱野雅 裕，佐伯宗大：高速道路盛土の震災事例による簡易 耐震性評価手法の検討, 第 55 回地盤工学シンポジウ 厶平成 22 年度論文集, pp.167-172, 2010.

20) 佐伯宗大，横田聖哉，高木宗男，中村洋丈，濱野雅 裕, 土谷基大 : 高速道路盛土の震後復旧シナリオを 想定した許容残留変形量の検討, 第 55 回地盤工学シ ンポジウム平成 22 年度論文集, pp.173-178, 2010.

21）国土交通省都市・地域整備局：大規模盛土造成地の 変動予測調査ガイドライン（案）の解説， 2008.
22）例えば，常田賢一，林健二：道路盛土の地震時危険 度のマクロ評価に関する検討, 第 43 回地盤工学研究 発表会発表講演集, pp.1927-1928, 2008.

23) 事業継続計画策定促進方策に関する検討会 ・内閣 府：事業継続ガイドライン第二版，2009.

24）国土交通省：国土交通省業務継続計画，2007.

25）日本道路協会：道路震災対策便覧(震前対策編), 2006.

26) 国土交通省 : 盛土のり面の緊急点検要領(案), 2008.

27）国土交通省新道路技術会議：道路政策の質の向上に 資する技術研究開発成果報告レポートNo.17-4, 2008.

28) 国土交通省 HP : http://www.mlit.go.jp/

29) 地盤工学会 : 2004 年新潟県中越地震災害調査報告書, pp.187-204, 2007.

30) 東日本高速道路(株), 中日本高速道路(株), 西日本高 速道路(株)：設計要領第一集 土工編, pp.6-19-6-26, 2010.

31) 日本道路協会 : 道路橋示方書 - 同解説 $\mathrm{V}$ 耐震設計編, pp.304-310, 2002.

32）佐々木哲也, 杉田秀樹, 大川寛, 水橋正典 : 2007 年 能登半島地震で被災した盛土における地盤調査, 土 木学会第 63 回年次学術講演概要集, pp.67-68, 2008.

33）日本道路協会 : 道路土工 軟弱地盤対策工指針, 1986.

34) 土木研究センター：土木構造物の震災復旧技術 マニ ユアル(案), 1986.

35) 内閣府 : 事業継続ガイドライン 第一版, 2005.

(2012. 8. 2 受付)

\title{
ESTABLISHING A SEISMIC ASSESSMENT METHOD FOR EARTHQUAKE DISASTER MANAGEMENT OF EXPRESSWAY EMBANKMENTS
}

\author{
Hirotake NAKAMURA, Seiya YOKOTA and Masahiro YOSHIMURA
}

When earthquakes strike, expressways function as emergency traffic routes for disaster relief and, therefore, quickly restoring their functions as "lines to connect points" is a must. In order to answer this need, expressway embankments must be quake-resistant, but currently, there are no effective rational ways to verify the earthquake-resistance of existing embankments. In this document, we will report on the required level of embankment performance from a management point of view and study results of the verification method selected based, in principle, on the following points: that it is comparatively simple to execute, the study procedure is systematic, the embankments for study are selected based on the fundamental conditions of the embankments, and the allowed displacement is decided following the recovery scenario created based on the amount of recovery work needed. Potions of expressways that were damaged by past disasters and actual model routes were selected based on the above criteria to check the effectiveness of the verification method when applied on actual expressway embankments. Through these studies we were able establish a rational and practical method of verification where we can systematically select the embankment for study, determine the residual displacement and set the allowable displacement. 